\title{
A PLAQUE ASSAY FOR CELLS MAKING ANTIBODY AGAINST HLA ANTIGENS
}

CENTRE FOR NEWFOUNDLAND STUDIES

\section{TOTAL OF 10 PAGES ONLY MAY BE XEROXED}

(Without Author's Permission)

YASMIN WASI 
0005

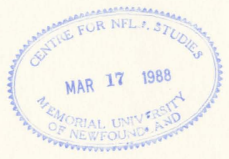





\title{
A PLAQUE ASSAY FOR CELLS MAKING ANTIBODY
} AGAINST HLA ANTIGENS

\author{
By \\ (C) Yasmin Wasi, B.Sc. (Hons.)
}

A thesis submitted to the School of Graduate

Studies in partial fulfillment of the requirements for the degree of

Master of Science

Faculty of Medicine

Memorial University of Newfoundland

November 1986

St. John's

Newfoundland 


\section{ABSTRACT}

Plaque assays that can detect single antibody-forming cells can be highly informative. A need was identified for a plaque assay which uses nucleated cells as targets, instead of the traditional erythrocyte targets. The objective of this thesis was to develop such an assay and to try it on some simple cellular problems in the field of monoclonal antibody technology.

The principle of the plaque assay was to use carboxyfluorescein diacetate to stain living, EBV-transformed target cells and a red fluorescent dye (propidium iodide) to stain the dead cells, in a plaque, that had been lysed by antibody and complement. A fluorescence microscope was then used to count the plaques. The final method involved the use of microscope slides for the assay and resulted in permanent preparations that could be stored and examined at leisure.

Trials with this technique using a mouse hybridoma, Nfld.M2, secreting cytotoxic antibody of anti-HLA-A2 and A28 specificity and of IgG2a subclass showed that less than $22 \%$ of these recently cloned cells formed plaques and that the majority of the cells were not secreting antibody, at least at levels detectable in this plaque assay. Efforts to increase the number of plaques by the use of a second antibody revealed a prozone effect. Another mouse hybridoma, Nfld.Ml, secreting non-cytotoxic antibody of anti-DR4 specificity and of IgG1 subclass was also used in the plaque assay. No plaques were obtained 
even with the addition of developing antiserum.

A human hybridoma, Nfld.H1, secreting cytotoxic antibody of IgM class was also used in the plaque assay. No plaques were observed and this was attributed to the low rate of antibody secretion by the hybridoma cells. When human EBV-transformed cells were used in the plaque assay as a source of antibody-secreting cells, clear and distinct plaques were obtained.

The experiments described here show that the plaque assay is suitable for use in analysing problems in cellular immunology in both mouse and human systems. The results have revealed at least one unexpected finding and this is the low proportion of antibody secreting cells found in a clone and ways are suggested for further research on these. Finally, the method for producing permanent preparations for immunofluorescence may find other applications for teaching or research. 


\section{ACKNOWLEDGEMENTS}

I would like to thank the following people:

Dr. W.H. Marshall for his excellent supervision, encouragement, and invaluable help in the completion of this thesis.

Dr. B. Larsen for her advice, support and helpful suggestions for this thesis.

Dr. R. Chandra, Ms. S. Drover and Mr. P. Avis for their helpful criticisms and ideas.

The Immunology group for their unfailing good humor and interest in this project.

My family for their patience and moral support without which this thesis would not have been possible.

Financial assistance was provided by grants from Health and Welfare Canada and from the Multiple Sclerosis Society of Canada. 


\section{Table of Contents}

Abstract
Acknowledgements
Table of Contents
List of Tables
List of Figures
List of Abbreviations

\section{CHAPTER 1}

Introduction

1.1. Immunofluorescent and Microdroplet techniques …………..................... 1

1.2. Hemolytic plaque assay .......................................................................... 5

1.3. Reverse hemolytic plaque assay .............................................................. 10

1.4. Enzyme-linked immunospot assay ....................................................... 12

1.5. Plaque assays using nucleated cells as target cells .................................. 15

1.6. Concluding remarks ........................................................................... 16

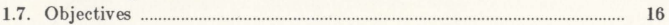

\section{CHAPTER 2}

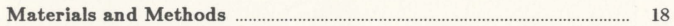

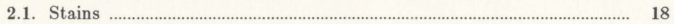

2.2. Target cells _........................................................................................... 18

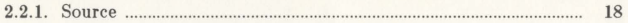

2.2.2. Procedure for preparing the cells for the assay ............................ 18

2.3. Antibody-secreting cells ...................................................................... 20

2.3.1. Source ................................................................................................. 20

2.3.1A. Mouse ……................................................................. 20

2.3.1B. Human ................................................................................... 21

2.3.2. Procedure for preparing the antibody-secreting cells for the assay ....................................................................................... $\quad 22$

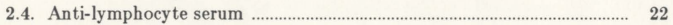

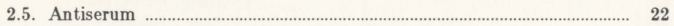

2.6. Trypan blue exclusion ........................................................................... ' 23

2.7. Procedure for concentrating supernatants ............................................. 23

2.8. Isolation of B lymphocytes ............................................................... 23

2.9. EBV-transformation ............................................................................ 25 
2.10. Complement dependent cytotoxicity ………….................................... 25

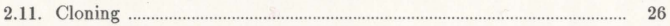

2.12. The plaque assay ................................................................................. 27

2.12.1. The petri dish method ............................................................ 27

2.12.2. Slide method \#1 ............................................................. 28

2.12.2A. Assembling microchambers ..................................... 29

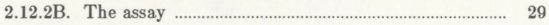

2.12.3. Slide method \#2 .................................................................... 31

2.12.3.A. Assembling microchambers ..................................... 31

2.12.3.B. The assay .................................................................. 31

2.12.4. Plaque size ………………......................................................... $\quad 34$

\section{CHAPTER 3}

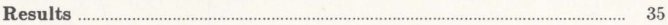

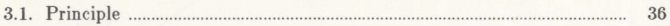

3.2. The petri dish method ……......................................................... 37

3.2.1. Concentration of target cells ..................................................... $\quad 37$

3.2.2. Experiments with anti-lymphocyte serum .................................... 38

3.2.3. Experiments with supernatants from Nfld.M2 cultures ............. 38

3.2.4. Experiments with hybridoma cells from Nfld.M2 cultures ................................................................................ 39

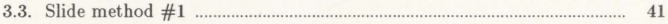

3.3.1. Capacity of the chambers .................................................... 41

3.3.2. Concentration of target cells ....................................................... 41

3.3.3. Complement volume ................................................................... 43

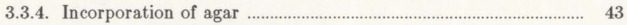

3.3.5. Non-specific leaking of fluorescein ............................................ 44

3.3.6. Experiments using various target cells with Nfld.M2
antibody

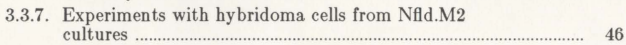

3.3.8. Addition of Propidium Iodide ................................................ $\quad 50$

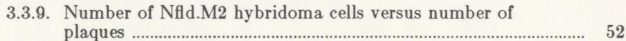

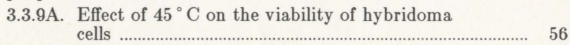

3.3.9B. Effect of $45^{\circ} \mathrm{C}$ on antibody secretion ........................... 56

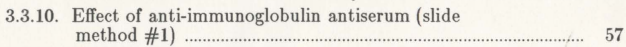




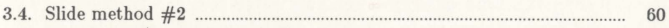

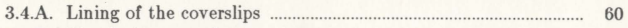

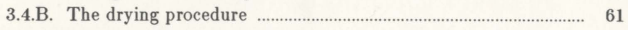

3.4.1. Complement titration ............................................................... 62

3.4.2. Number of hybridoma cells versus number of plaques .............. 62

3.4.3. Comparison of slide method \#1 with slide method \#2 ............ 63

3.4.4. Effect of anti-immunoglobulin antiserum (slide method \#2) …….................................................................. 63

3.5. Some applications of the plaque assay …………................................... 66

3.5.1. Cloning of Nfld.M2 hybrids ..................................................... 66

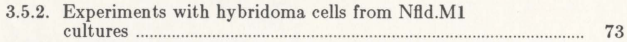

3.5.3. Experiments with supernatant from Nfld.H1 cultures

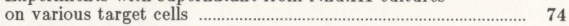

3.5.4. Experiments with EBV-transformed cells as ASC ..................... $\quad 75$

\section{CHAPTER 4}

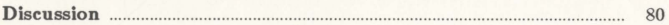

4.1. Specificity of the plaque assay ............................................................. 80

4.2. Comparison of slide method \#1 with slide method \#2 …..................... 82

4.3. Percentage of Nfld.M2 hybridoma cells forming plaques ..................... 82

4.4. Effect of anti-immunoglobulin antiserum ………................................. 85

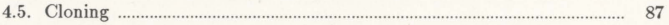

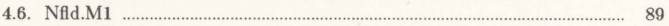

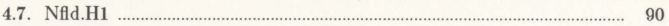

4.8. EBV-transformed cells ......................................................................... 91

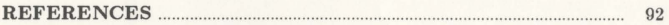




\section{LIST OF TABLES}

Table 1. The HLA phenotypes of various target cell lines 19

Table 2. Degree of lysis of target cells with decreasing concentrations of Nfld.M2 hybridoma cells (petri dish method)

Table 3. HLA specificity of Nfld.M2 demonstrated as lysis of target cells using slide method \#1

Table 4. Effect of serial dilutions of anti-Ig antiserum (As) on the number or size of plaques formed (slide method \#1).

Table 5. The number of plaques formed per 5000 Nfld.M2 hybridoma cells are compared for slide method \#1 and method \#2

Table 6. Effect of serial dilutions of anti-Ig antiserum (As) on the number or size of plaques formed (slide method \#2)

Table 7. Degree of lysis of various target cells when tested with concentrated ( 50 fold) Nfld.H1 antibody (slide method \#2)

Table 8. Number of plaques formed with human PBLs collected and transformed with EBV at various days postimmunization 


\section{LIST OF FIGURES}

Figure 1. Slide method \#1 ..................................................30

Figure 2. Slide method \#2 …...................................................32

Figure 3. Negative control, slide method \#1..............................42

Figure 4. Total target cell lysis, slide method \#1 ........................48

Figure 5. Confluent plaques, slide method \#1.............................49

Figure 6. Single plaque, slide method \#1 ...................................51

Figure 7. PI staining of dead cells, slide method \#2 …................53

Figure 8. PI staining of dead cells, slide method \#2 ...................54

Figure 9. Number of plaques formed as a function of number of hybridoma cells plated (slide method \#1)......................55

Figure 10. Number of plaques formed as a function of number of hybridoma cells plated (slide method \#2).......................64

Figure 11. Change with time after cloning in percent of hybridoma cells secreting antibody (slide method \#2)...................69

Figure 11a: Clone1 …...............................................70

Figure 11b: Clone2 …..................................................71

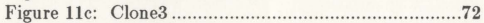




\section{LIST OF ABBREVIATIONS}

AFCF Antibody-forming cell focus assay

ALS Anti-lymphocyte serum

ASC Antibody-secreting cells

BSS Balanced salt solution

CDC Complement dependent cytotoxicity assay

CFDA Carboxyfluorescein diacetate

EBV Epstein-Barr virus

ELISA Enzyme-linked immunosorbent assay

ELISPOT Enzyme-linked immunospot assay

FCS $\quad$ Fetal calf serum

FIPA Filter immunoplaque assay

NSRBC Neuraminidase-treated sheep red blood cells

PBLs Peripheral blood lymphocytes

PBS Phosphate-buffered saline

PFC Plaque-forming cells

PI Propidium iodide

RBC Red blood cells

RHPA Reverse hemolytic plaque assay

SRBC Sheep red blood cells 


\section{CHAPTER 1}

\section{INTRODUCTION AND OBJECTIVES}

A method capable of detecting individual cells secreting anti-HLA antibody is described in this thesis. Single cell methods for detecting antibodyforming cells have been in existence for many years and have been developed and modified to aid in counting and identifying cells forming and secreting antibody; however, with few exceptions, they either involved red cells as targets or else were delicate and demanding techniques, involving the use of micromanipulation. The aim of this study was to develop a method where nucleated cells are used as targets. In this chapter, some of the earlier published methods and their uses will be reviewed.

\subsection{Immunofluorescent and Microdroplet techniques}

Most of the earlier single cell methods were developed and used for the purpose of identifying antibody-forming/secreting cells. Reiss, Mertens and Ehrich (1950) demonstrated antibody-forming cells in the lymph nodes of immunized rabbits by the method of bacterial adherence. Cell suspensions made from these lymph nodes were incubated along with the bacteria of the immunizing strain on a slide and observed microscopically. They noted that certain lymphoid cells from these lymph nodes agglutinated on their surface the bacteria of the immunizing strain. They identified these antigen-binding 
cells as being members of the plasma cell series, thus confirming the observations of Fagraeus (1948) who was one of the first investigators to suggest, from morphological observations, that antibody-forming cells belonged to the plasma cell series. She had examined spleens from immunized animals and had found that cells identified as plasmablasts began to appear 2 or 3 days after antigen administration.

Coons, Leduc and Connolly (1955) examined various organs and tissues from hyperimmune rabbits for antibody-containing cells using the fluorescent antibody technique. This technique had been developed by Coons, Creech, Jones and Berliner in 1942. They showed that fluorochromes could be conjugated to antibody without altering the ability of the antibody to combine with antigen. To demonstrate the presence of antibody in various organs and tissues from immunized animals, they incubated frozen sections of these tissues with the appropriate antigen followed by the conjugated antibody to the same antigen. Antibody-containing cells fluoresced when viewed under a fluorescence microscope. They demonstrated these antibody-containing cells in the red pulp of the spleen, the medullary areas of the lymph nodes, the submucosa of the ileum and the portal connective tissue of the liver. These antibodycontaining cells were identified as plasma cells.

Nossal and Lederberg (1958) described a single cell technique in which antibody production by single cells isolated in microdroplets could be detected. In this technique, popliteal lymph nodes from rats immunized with Salmonella 
flagellar antigen were removed and processed to give a cell suspension. Single cells were isolated in microdroplets (volume: $10^{-7}-10^{-6} \mathrm{ml}$ ) on the surface of a coverslip and then immersed in paraffin oil. The coverslip was then inverted over a chamber filled with oil and incubated at $37^{\circ} \mathrm{C}$ for a few hours. The chambers were next placed on the stage of a microscope. With the aid of a micropipette, bacteria of the immunizing strain were instilled into each microdroplet. The presence of anti-flagellar antibody was detected by specific immobilization of these bacteria.

Using this technique, Nossal and Lederberg demonstrated the validity of the one-cell-one-antibody theory. They immunized rats with two antigens and found that single cells made antibody to one or the other antigen but not to both. Nossal (1959b) showed that the difference between primary and secondary responses was due to the fact that the proportion of cells actively secreting antibody was far higher in the secondary response. This was also shown by Leduc, Coons and Connolly (1955) by the fluorescent antibody technique. Nossal (1959) also confirmed that most of the antibody-producing cells resembled plasma cells.

The work of Nossal was further improved by using bacterial adherence to preselect antibody-forming cells from among a mixed population of antibodyforming and non-antibody-forming cells; these marked cells could then be removed with a micropipette for use in detailed single cell studies (Mäkelä and Nossal, 1961). Nossal, Szenberg, Ada and Austin (1964), using this technique, 
demonstrated the phenomenon of isotype switching. They showed the sequential appearance of $\operatorname{IgM}$ and $\operatorname{IgG}$ antibody for the primary and secondary responses, respectively. Cell suspensions were made from lymph nodes after primary and secondary immunizations (the secondary immunization was 6-8 weeks after the primary) in rats. Bacterial adherence positive cells were isolated individually in microdroplets and incubated as usual. Following the incubation, a small sample of each drop was removed, diluted and then divided into four equal parts. Droplets in the first group were treated with mercaptoethanol while droplets in the second group were treated with anti-7S globulin serum. Those in the third group were treated sequentially with both. The fourth group of droplets was left undisturbed. The untreated and doubly treated microdroplets served as positive and negative controls, respectively. Bacteria were then added to each droplet. The cells in the droplets that had been treated with mercaptoethanol and could not immobilize the bacteria were classified as IgM producers. The cells in the droplets that had been treated with the anti-7S serum and had lost their immobilizing activity but were unaffected by mercaptoethanol were classified as $7 \mathrm{~S}$ producers. The cells in the droplets that showed antibody activity in both the mercaptoethanol treated and the anti-7S treated but no activity in the doubly treated droplet were classified as double producers.

The single cell techniques described above, although effective, were tedious with very limited screening power in terms of detecting rare antibody- 
producers among a large excess of non-producers.

\subsection{Hemolytic plaque assay}

In 1963, Jerne and Nordin developed a plaque assay which enabled them to enumerate rare antibody-forming cells in a mixed cell population. In this assay, popliteal lymph nodes removed from rabbits immunized with sheep red blood cells were processed to give a cell suspension. These lymphoid cells together with agar and target erythrocytes were plated in a petri dish precoated with a bottom layer of agar and were incubated for one hour. The incubation allowed the lymphoid cells to secrete antibody which bound to the sheep red blood cells (SRBC). Guinea pig complement was then added and the petri dish incubated for another hour. At this stage, the complement caused lysis of the sensitized red cells, resulting in plaques which were visible as small, round areas of hemolysis against the uniformly red background. These plaques could be seen with the naked eye or visualized through a low power dissecting microscope. The importance of this technique was that literally millions of cells could be screened quickly for the presence of rare antibody-forming cells.

A short time later, Ingraham and Bussard (1964) introduced another localized hemolysis in gel technique. They used carboxymethyl cellulose as the thickening agent rather than agar, and microscope slides rather than petri dishes. A mixture of lymphoid cells from immunized animals, guinea pig complement and carboxymethyl cellulose containing SRBC was pipetted onto 
microscope slides which were divided into two rectangular areas by the use of gummed label paper. Coverslips were then placed on the slides and sealed around the edges with melted vaseline.

Cunningham (1965) introduced a modification of the Jerne-Ingraham technique. His was a free suspension, monolayer technique requiring no supporting medium. A mixture of antibody-producing cells, complement and target erythrocytes was placed in shallow circular chambers on microscope slides. The cell suspension settled at the bottom to form a monolayer. The chamber was then covered with a coverslip, and sealed with melted vaseline. This technique was found to be more sensitive and offered better resolution than the Jerne-Ingraham technique.

In investigations aimed at a detailed study of the morphology of single antibody-forming cells, Cunningham, Smith and Mercer (1966) further modified the technique for the purpose of micromanipulating the plaqueforming cells, since in the above technique the coverslips made the plaqueforming cells inaccessible. A shallow chamber was prepared by painting vinyl plastic around the edges of a microscope slide and this chamber was then filled with paraffin oil. A drop of a mixture of lymphoid cells from immunized animals, SRBC and complement was then introduced under the oil with a fine pipette. The cells formed a monolayer and the plaque-forming cells that were identified could be removed with a micropipette attached to a micromanipulator and examined under a light microscope for morphological studies. 
The Jerne hemolytic plaque assay was thought to detect only those cells secreting antibody of IgM class. Šterzl and Řiha (1965) as well as Dresser and Wortis (1965) showed that by adding anti-IgG sera, after primary incubation with antibody-secreting cells, cells producing non-complement fixing antibody, or antibody of low hemolytic efficiency could be detected. This technique was further extended to the detection of plaque-forming cells of all classes and subclasses by the use of appropriate antisera.

Mishell and Dutton (1967) who used the plaque assay to study primary immune responses in vitro, used microscope slides rather than petri dishes, and agarose instead of agar. This method was found to be more economical since it required smaller amounts of reagents.

Cunningham and Szenberg (1968) introduced another modification of their free suspension technique whereby the size of the chambers was increased for greater screening power. They prepared microscope slides by using four strips of double adhesive scotch tape to divide it into three equal parts. Coverslips were then pressed on to form three chambers. These chambers were then filled by capillary action with a mixture of lymphoid cells from immunized animals, erythrocytes and complement and sealed with melted vaseline. Anti-Ig sera was also added for indirect plaques.

Nossal, Bussard, Lewis and Mazie (1970) introduced an 'open system' modification of the Ingraham-Bussard technique. This technique made the 
plaque-forming cells accessible for micromanipulation. A mixture of lymphoid cells from immunized animals, SRBC, complement and carboxymethyl cellulose was pipetted onto coverslips which were then immersed in paraffin oil.

Kennedy and Axelrad (1971) introduced another monolayer plaque assay. In this assay, advantage was taken of the fact that the surface of a plastic petri dish is negatively charged. Poly-L-lysine, which is positively charged, was used to coat the negatively charged surface of the plastic petri dishes. A monolayer of negatively charged SRBC was then bound on to the positively charged poly-L-lysine. A mixture containing the antibody-producing cells and complement was then added and allowed to settle into a monolayer. By exposing the petri dishes to gluteraldehyde vapour after plaque formation, permanent preparations could be made for radioautographic and morphological studies which had not been possible with the other techniques.

Lefkovits (1972) introduced a plaque assay that could be performed in microwell plates. In this test, spleen cells stimulated with heterologous red cells were removed from microcultures and transferred with a replicator to microwell plates containing bottom agar. The replicator could simultaneously remove samples from 60 wells of a tissue culture plate and release them on an assay plate (Lefkovits and Kamber, 1972). The droplets of cells were allowed to soak into the agar and were then overlaid with top-agar containing red cells and incubated. Complement was then added. This method had the advantage of allowing a large number of samples to be screened as well as requiring 
smaller volumes than the slide or petri dish method.

Kappler (1974) introduced a free suspension plaque assay that could be done in microwell plates. SRBC, complement and antibody-producing cells were added to each well of the microwell plate. The cell mixture settled at the bottom to form a monolayer. Plaques were scored by viewing with a low power stereoscopic microscope with indirect transmitted light.

Kissinger and Myl (1984) introduced a capillary glass microslide method. The microslides were custom-made by Vitro-Dynamics and did not require assembly like Cunningham chambers. The microslide method was found to be as sensitive as the method of Cunningham. A mixture of SRBC, antibodysecreting cells and complement was pipetted into the microslides through capillary action. The microslides were then sealed with a paraffin-petrolatum mixture. The plaques could either be counted under a low power microscope or they could be electronically counted by the use of the Artek Systems Counter Model 980 (Katz, Faulkner, Katz, Lindh, Leonhardt, Herr and Tung, 1977). The latter allows rapid, semi-automated counting of plaque-forming cells directly from the slides on which they are developed, and depends on the change in optical density that occurs when an area of red cells is lysed.

The techniques described above only allow the detection of anti-red cell antibody. By artificially coupling proteins, polysaccharides, or haptens, to red blood cells, cells secreting antibodies to these could also be detected (Jerne, 
Henry, Nordin, Fuji, Koros and Lefkovits, 1974). To detect cells secreting antibody to antigens that could not be readily coupled to SRBC, Bagasara and Damjanov (1982) described a latex bead technique. They used a bacterial antigen that could not be coupled to SRBC but was readily adsorbed onto latex beads. A mixture of antibody-secreting cells, SRBC, antigen-conjugated latex beads, complement and agarose were poured onto slides and incubated. It was postulated that plaques formed, when the antigen-antibody complexes bound to latex beads, activated the complement which caused lysis of nearby red blood cells.

\subsection{Reverse hemolytic plaque assay}

In 1974, Molinaro and Dray introduced the first reverse hemolytic plaque assay (RHPA). SRBC were coated with anti-human Ig antibody and a mixture of these with agarose and peripheral blood lymphocytes was plated on petri dishes. Antiserum to human Ig (developer) and complement were added after incubation. Plaques developed at the site of any antibody-secreting cell, irrespective of the antigenic specificity, because the anti-Ig on the SRBC would bind the human Ig which would in turn bind the anti-human Ig and this complex would then activate the complement system. When the developing antibody was omitted from the assay, no plaques were found. Eby, Chong, Dray and Molinaro (1975) later applied this technique for enumerating Ig-secreting cells in non-immunized individuals as a measure of B-cell function. 
Ginsburg, Finkelman and Lipsky (1978) by using class-specific anti-Ig (developing antibody) were able to determine the class of Ig secreted.

Gronowicz, Coutinho and Melchers (1976) described another RHPA. In this assay, protein A from Staphylococcus aureus which binds to the Fc region of IgG was used to coat red cells. The protein A-coated red cells were incubated in petri dishes together with the antibody-secreting cells, agar, complement and the IgG fraction of an antiserum, specific for one or more classes of antibody. The secreted Ig formed a complex with the corresponding IgG molecules of the antiserum and these complexes bound to the protein $\mathrm{A}$ on the red cells. The complexes activated complement resulting in lysis of the red cells to which they were bound.

Bird and Britton (1979) later adapted the protein A technique to the human system.

The RHPA described above usually incorporated agar or agarose in the assay. Two groups introduced a fluid phase technique (Pryjma, Muñoz, Virella and Fudenberg, 1980; Beaudoin, Valet and Hébert, 1980). A mixture of protein A-coated SRBC, antibody-secreting cells, antiserum and complement was pipetted between two microscope slides held together by double-sided adhesive tape. The slides were then sealed with paraffin.

Pang, Gatman, Drummond and Booth (1981) introduced a micromethod form of the RHPA. A mixture of protein A-coated SRBC and lymphocytes 
was added to flat-bottomed 96-well microtitre plates which were spun at low speed to give a monolayer of cells at the bottom of each well. After incubation, antiserum was carefully added to each well followed by another incubation, and then the addition of complement.

Librach and Mackay (1982) modified the micromethod further by using the same microwell plates for the plaque assay that were used for culturing cells. The microwell plates containing the antibody-secreting cells were centrifuged and the supernatant discarded by inverting the plates. The cells were resuspended and to each well was then added erythrocytes, antiserum and complement. The plaques were scored with a stereosean microscope. In comparing the solid-phase and the liquid-phase system, it was observed that the latter was the more sensitive assay (Wangel, Poikonen and Eskola, 1984).

The RHPA is still quite extensively employed by investigators for the purpose of studying in vitro activation of human peripheral blood B lymphocytes by such mitogens as pokeweed mitogen and Epstein-Barr virus (EBV), and for enumerating individual subpopulations secreting Ig of a specific isotype, allotype or idiotype by the use of appropriate antisera.

\subsection{Enzyme-linked immunospot assay}

In 1983, Czerkinski, Nilsson, Nygren, Ouchterlony and Tarkowski as well as Sedgwick and Holt (1983) introduced a solid phase enzyme-linked immunospot (ELISPOT) assay, based on the principles of the enzyme-linked 
immunosorbent assay (ELISA) system, for enumerating specific antibodysecreting cells as well as for quantitating the amount of antibody secreted. Antibody-secreting cells were added to antigen-coated (eg. ovalbumin) petri dishes. The dishes were then incubated and rinsed followed by the addition of an anti-Ig serum conjugated to enzyme. Then, after incubation and rinsing, an agarose-substrate solution was added to the dishes and immediately flicked off to leave a thin film of gel. Where antibody-production had occurred, spots appeared which were dark-brown or blue, depending on the chromagen used, and which could be counted with the naked eye or under low magnification. For quantitation of secreted antibody, all the steps performed were as described for the immunospot assay, but instead of adding agarose-substrate, a liquid solution of substrate was added to each dish. The samples were then transferred to micro-ELISA plates and the absorbance values were recorded with a multi-channel spectrophotometer.

Czerkinski, Tarkowski, Nilsson, Ouchterlony, Nygren and Gretzer (1984) as well as Holt, Cameron, Stewart, Sedgwick and Turner (1984) also introduced a reverse ELISPOT. Antibody-secreting cells were added to petri dishes coated with anti-Ig. After a period of incubation, conjugate was added followed by substrate.

Möller and Borrebaeck (1985) described a filter immunoplaque assay (FIPA) capable of screening several hundred samples a day. In this assay, antibody-secreting cells were incubated on antigen-coated nitrocellulose 
membranes in micro-filter plates or in petri dishes. The products of specific antibody-producing cells were then detected by the addition of conjugated secondary antibody and substrate.

The ELISPOT assay seems to be of equivalent or greater sensitivity to existing plaque techniques and is especially useful in enumerating antigenspecific Ig-secreting cells in which the antigen is difficult to couple to red cells. Since it is not dependent on the use of complement-mediated lysis, it eliminates any errors due to the variation in susceptibility of target erythrocytes to lysis. Other investigators have also introduced assays which are not dependent on complement-mediated lysis. To mention a few, Pick and Feldman (1967) introduced an autoradiographic technique. Microscope slides were coated with a mixture of lymph node cells from immunized rats together with agarose. The Ig secreted by the cells was precipitated by anti-Ig and revealed by radiolabelled antigen. Moore and Calkins (1983) introduced an antibody-forming cell focus assay (AFCF). The Ig secreted by cells was immobilized by the anti-Ig used to coat petri dishes. Erythrocytes were then added to the petri dishes which were incubated and then washed gently to remove any unattached red blood cells (RBC). The antibody-secreting cells were revealed by the formation of foci of intact erythrocytes around the Ig-secreting cells. These methods are not as sensitive as the ELISPOT and are more timeconsuming and tedious to perform. 


\subsection{Plaque assays using nucleated cells as target cells}

In 1971, Fuji, Zaleski and Milgrom applied the plaque technique to nucleated cells, using thymus cells (Thy-1) and lymphoblast (H-2) target cells instead of red cells. The spleen cells from immunized mice, nucleated target cells, and agar were spread evenly on microscope slides and incubated. The slides were then flooded with complement, incubated and finally fan-dried and fixed with ethanol. The plaques appeared as clear areas of localized cytolysis.

Nordin, Cerottini and Brunner (1971) described a similar assay in which they used allogeneic tumor cells as target cells. After plaque formation, which took 24 hours, the slides were fixed with ethanol and stained with Giemsa stain. Giemsa stained the intact cells and not those that had been lysed.

Taylor and Bennett (1973) introduced a modification of this technique. They stained the petri dishes with trypan blue after plaque formation, so as to stain lysed cells preferentially.

Unlike the methods involving red cells as targets, the techniques devised for nucleated target cells have never come into general use. A recent computer search of the literature between 1970 and 1986 produced only five papers where these methods had been used in research (Lake, 1976; Nakashima and Lake, 1979; Nakashima, Mizoguchi, Kato, Nagase, Isobe, Saito and Suzuki, 1982; Nakashima, Clark, Lake, Kato, Nagase, Mizoguchi, Isobe and Saito, 1983; Mizoguchi, Nakashima, Isobe, Saito, Nagase, Kato and Shimokata, 
1984).

\subsection{Concluding remarks}

In the 23 years, since the invention of the hemolytic plaque method by Jerne and Nordin, that technique has been applied to virtually every problem in cellular immunology. The use of red cells as targets has been the key feature of most of these experiments. The far smaller number of publications which involve the use of nucleated cells as targets, presumably reflects, in part at least, the less satisfactory state of the latter technique. In this thesis, a method using fluorescein-labelled EBV-transformed cells as targets is described. It was felt that the sharp contrast between the live and dead cells, that is, the fluoresceinated and the non-fluoresceinated (or alternatively, propidium iodide-stained) cells, respectively, would provide a clearer and better definition of plaques than the earlier methods.

\subsection{Objectives}

A plaque assay capable of detecting cells making anti-HLA antibody has many applications and would be particularly useful to an investigator engaged in making monoclonal antibodies to HLA antigens. It could be used to monitor the frequency of specific antibody-forming cells in the blood of humans at intervals after immunization or pregnancy; to monitor cellular manipulations such as the effectiveness of an enrichment procedure for specific cells; to determine if there are any antibody-forming clones developing in post-immunization 
mixed lymphocyte cultures; to check the clonality of a cloned hybridoma culture; to monitor the frequency of specific antibody-forming EBV-transformed cells as compared to the overall culture; to investigate the problem of the loss of specific antibody-secreting clone(s) in a polyclonal EBV-stimulated culture that usually occurs after a few weeks of the cells in culture. The most ambitious application of this plaque assay would be to identify specific plaqueforming cells and then to remove them by micromanipulation for cloning or fusion.

The objectives of this study were:

(1) To develop a plaque assay against nucleated target cells using mouse hybridoma cells that are known to secrete high levels of cytotoxic antibody.

(2) If this was successful, then to explore the possibility of adapting the method to detecting human antibody-secreting cells, such as human hybridoma cells, to see if specific plaques could be produced with these.

(3) To apply the plaque assay to one or more of the problems mentioned above, if time permitted. 


\section{CHAPTER 2}

\section{MATERIALS AND METHODS}

\subsection{Stains}

Two stains were used in the plaque assay. Carboxyfluorescein diacetate (CFDA, Molecular Probes Inc., 24750 Lawrence Road, Junction City, OR., U.S.A.) was used to stain living cells. Propidium iodide (PI, Sigma, St. Louis, Missouri 63178 , U.S.A.) was used to stain dead cells.

\subsection{Target cells}

\subsubsection{Source}

Epstein-Barr virus (EBV)-transformed cell lines from 11 adults were used in these experiments (Table 1). All except GM3161 were produced in this laboratory from patients or healthy individuals. GM3161 was obtained from the Human Genetic Mutant Cell Repository (Camden, N.J. 08103, U.S.A.).

\subsubsection{Procedure for preparing the cells for the assay}

These cells were cultured in Roswell Park Memorial Institute (RPMI) 1640 medium supplemented with $2 \mathrm{mM}$ L-glutamine, $1 \mathrm{mM}$ sodium pyruvate and $10 \%$ heat inactivated fetal calf serum (FCS, Flow Labs., Mclean, Virginia 22102 , U.S.A.) at $37^{\circ} \mathrm{C}$ in a humidified $\mathrm{CO}_{2}$ incubator. No antibiotics were used. They were harvested while in the $\log$ phase of growth and at greater 
Table 1

The HLA phenotypes of target cell lines used

\begin{tabular}{|c|c|c|c|c|c|}
\hline \multirow{2}{*}{ Target Cell Line } & \multicolumn{5}{|c|}{ HLA Phenotypes } \\
\cline { 2 - 6 } & A & B & C & DR & DQ \\
\hline E.A. & 1,2 & 8,14 &,-- & 2,3 & w1 \\
\hline B.C. & 1,2 & $5, ? 17$ & w3,w6 & 4,5 & w3,w3 \\
\hline D.C. & 3 & $? 5,15$ & w4,?w6 & $2, ?$ w6 & w1 \\
\hline E.C. & 1,3 & $7,-$ & w6 & 2 & w1,- \\
\hline M.C. & 1,24 & 7,18 & w4 & 2,3 & w1,w3 \\
\hline K.H. & 1,2 & 8 & w1,- & 3,4 & w2,w3 \\
\hline C.A.K. & 1,24 & 7,44 & w2,6 & 2,5 & w1,w3 \\
\hline C.H.M. & 1,2 & 8,40 & w3 & 1,3 & w1,w2 \\
\hline L.R. & $3, \mathrm{w} 24$ & 7,15 & w1 & 2, w9 & w1 \\
\hline T.P. & 2,28 & 18 &,-- & 2,4 & w1,w3 \\
\hline GM3161 & 1,2 & $12,-$ & w3,- & 2,2 & w1 \\
\hline
\end{tabular}


than $90 \%$ viability as determined by phase contrast microscopy or by trypan blue exclusion (section 2.6). They were counted in a Neubauer hemocytometer and appropriate volumes were pipetted from the cultures for use in the assay. They were centrifuged and washed twice in phosphate-buffered saline (PBS), $\mathrm{pH} 7.4$ at $500 \mathrm{~g}$ for 10 minutes each and resuspended at a concentration of 15 million target cells per $1 \mathrm{ml}$ of a working solution of CFDA. The CFDA working solution was made by adding $80 \mu \mathrm{l}$ of the stock solution (100 mg of CFDA in $10 \mathrm{ml}$ of acetone) to $10 \mathrm{ml}$ of PBS. The cells were incubated at $37^{\circ} \mathrm{C}$ for 20 minutes and washed three times in PBS at $500 \mathrm{~g}$ for 10 minutes each. The pellets were then resuspended in appropriate volumes of PBS.

\subsection{Antibody-secreting cells}

\subsubsection{Source}

2.3.1A. Mouse

Nfld.M1: Nfld.M1 is a locally produced mouse-mouse hybridoma (Drover, Marshall and Younghusband, 1985). It resulted from a fusion between immune spleen cells from a Balb/c mouse and SP2/O-Ag14, a nonsecreting mouse plasmacytoma (Shulman, Wilde and Köhler, 1978). It secretes non-cytotoxic antibody of anti-HLA-DR4 specificity and of IgG1 subclass.

Nfld.M2: Nfld.M2 is another locally produced mouse-mouse hybridoma (Drover, Marshall and Mervart, in preparation). It resulted from a fusion 
between immune spleen cells from a Balb/c mouse and SP2/O-Ag14. It secretes cytotoxic antibody of anti-HLA-A2 and HLA-A28 specificity and of IgG2a subclass.

\subsubsection{B. Human}

Nfld.H1: Nfld.H1 is a locally produced human-human hybridoma (Drover, Codner, Fuad, Marshall, Mervart, Wasi and Yun, in preparation). It resulted from a fusion between an EBV-transformed cell line from a recently delivered multiparous woman and KR4, a human fusion partner (Kozbor, Lagarde and Roder, 1982). This human monoclonal antibody is of IgM class, and only reacts significantly with EBV-transformed B cell lines and not with peripheral or umbilical cord blood $\mathrm{T}$ and/or B cells. At high dilutions, it reacts with cell lines that carry HLA-DR2 and HLA-DQw1, however, the precise nature of the molecule(s) with which it binds has not yet been established.

EBV-transformed cells as antibody-secreting cells: These were EBV-transformed cells made from B cells obtained from an immunized adult male volunteer (W.H.M.). The immunization, which was fully approved by the Human Investigations Committee, was done by injecting $5 \times 10^{7}$ peripheral blood lymphocytes (PBLs) from another male volunteer (C.H.M.), intradermally at four sites on six occasions (March, 1983; April, 1983; June, 1983; November, 1983; January, 1984; April, 1985). The PBLs were in $20 \%$ heat inactivated autologous serum in RPMI and $0.1 \mathrm{ml}$ was injected at each site. 
W.H.M. was bled on Day 1, 4, 7, 11, 14, 19, 22, 25, 28, 32, 35, 39 and 42 following the sixth immunization in April, 1985. The B cells were then isolated from these blood samples (section 2.8) and were transformed with EBV (section 2.9). These transformed $B$ cells were used in the plaque assay as a source of antibody-secreting cells.

\subsubsection{Procedure for preparing the antibody-secreting cells for the} assay

The preparation of the antibody-secreting cells was the same as described earlier for the target cells (section 2.2.2). The cells were resuspended in PBS but were not labelled with CFDA.

\subsection{Anti-lymphocyte serum}

Anti-lymphocyte serum (ALS) was used in the initial experiments. It was produced locally in $\mathbf{1 9 7 4}$ for use as a positive control in HLA typing, by immunizing a rabbit repeatedly with human thymus cells.

\subsection{Antiserum}

The antiserum used was a commercially available rabbit anti-mouse IgG, IgA and $\operatorname{IgM}(\mathrm{H}+\mathrm{L})$ (Dako Labs. from Cedarlane Labs. Ltd. 5516-8th Line, R.R.2 Hornby, Ont., Canada). 


\subsection{Trypan blue exclusion}

The trypan blue solution was prepared by adding $0.3 \mathrm{ml}$ of $1 \%$ trypan blue (prepared in water) to $0.7 \mathrm{ml}$ of $2 \%$ EDTA buffer. To $0.1 \mathrm{ml}$ of this solution was added $0.1 \mathrm{ml}$ of cell suspension. After gently mixing, a small volume was removed with a pasteur pipette and used to fill a Neubauer hemocytometer. The chamber was then examined under a microscope and the percent viability was determined by dividing the number of live cells (cells that excluded trypan blue) by the total number of cells and multiplying it by 100 .

\subsection{Procedure for concentrating supernatants}

Supernatant obtained from Nfld.H1 culture was concentrated using Minicon-B15 Concentrators (Amicon Corp., Danvers., MA 01923, U.S.A.) which are disposable multiple ultrafilters. They consist of sample chambers which are marked on the outside with graduation lines indicating the concentration ratios. A sample can be concentrated up to 100 -fold. The supernatant was applied through the opening at the top of the sample chamber of the miniconcentrator with a pasteur pipette and left to stand until the desired concentration was reached. The concentrated sample was then removed with a pasteur pipette.

\subsection{Isolation of $B$ lymphocytes}

Lymphocytes were isolated by the Ficoll/Hypaque density method 
(Böyum, 1968). All the manipulations were done using sterile technique. Heparinized blood was diluted 1:2 in PBS and layered gently on top of Ficoll Hypaque (Pharmacia, Dorval, Quebec, Canada, density: 1.077) at a ratio of 2:1 of blood to Ficoll in a $50 \mathrm{ml}$ tube. The tube was then centrifuged at $500 \mathrm{~g}$ for 20 minutes. After centrifugation, the mononuclear layer was removed carefully from the interface with a pasteur pipette and put in a tube containing an equal volume of Hank's balanced salt solution (BSS) without calcium and magnesium (Flow Labs.). The cells were centrifuged and washed twice in Hank's BSS at $400 g$ for 10 minutes to remove the residual Ficoll and most of the platelets and were then resuspended in culture medium (RPMI 1640 containing L-glutamine, sodium pyruvate and $10 \%$ heat inactivated FCS) at a concentration of $5 \times 10^{6}$ lymphocytes per $\mathrm{ml}$.

The B cells were then purified by the following procedure: to a sterile, polystyrene culture tube $(12 \times 75 \mathrm{~mm}$, Fisher Scientific Co., Pittsburgh, PA 15219, U.S.A.) was added $2 \mathrm{ml}$ of cell suspension and $2 \mathrm{ml}$ of neuraminidase treated sheep red blood cells (NSRBC; Weiner, Bianco and Nussenzweig, 1973). The tube was rotated on a rotator at medium speed for 15 minutes and then centrifuged at $500 \mathrm{~g}$ for 5 minutes. After centrifugation, half of the supernatant was removed and the pellet was resuspended gently with a pasteur pipette. Approximately, $0.5 \mathrm{ml}$ of Ficoll Hypaque was then layered under the cell suspension and the tube was centrifuged at $350 \mathrm{~g}$ for 20 minutes. The layer at the interface containing the B cells was removed carefully and washed twice 
in culture medium for 10 minutes at $500 \mathrm{~g}$. Finally, the pellet was resuspended in an appropriate volume of culture medium for transformation with EBV.

\subsection{EBV-transformation}

The $\mathrm{B}$ cells were resuspended at a concentration of $1 \times 10^{6}$ per ml. To sterile Fisher snap top tubes $(12 \times 75 \mathrm{~mm})$ were added $0.5 \mathrm{ml}$ of the B cells and $0.5 \mathrm{ml}$ of $1 / 16$ dilution of EBV, prepared from the EBV-transformed marmoset lymphoblastoid cell line B95/8 (Miller and Lipman, 1973) which was kindly provided to us by Dr. M.J. Hobart, Cambridge, U.K. The tubes were then incubated at $37^{\circ} \mathrm{C}$ in a $\mathrm{CO}_{2}$ incubator and fed after five days. All the subsequent feedings were done twice a week by removing half of the supernatants with pasteur pipettes and replenishing them with fresh culture medium.

\subsection{Complement dependent cytotoxicity}

Complement dependent cytotoxicity assay (CDC) was developed by Terasaki and McClelland in 1964. The 60-well microtitre plates (Nunc Products, Roskilde, Denmark) used for the assay were prepared by the addition of a drop of light paraffin oil to each well. One $\mu \mathrm{l}$ of one of the following was then added to each well under the oil with a graduated microsyringe (Hamilton Co. Inc., Whittier, California, U.S.A.).

(i) supernatant to be tested, or

(ii) $10 \% \mathrm{FCS}$ in RPMI 1640 , negative control, or 
(iii) ALS, positive control

Then $1 \mu \mathrm{l}$ of target cells $\left(2 \times 10^{6}\right.$ per ml) was added to each well and the plates were incubated at room temperature. All incubations were done at room temperature. After 1 hour, $5 \mu \mathrm{l}$ of rabbit complement (HLA-ABC or DR rabbit complement from Pel Freez, Brown Deer, Wisconsin 53223, U.S.A.) was added with a multi syringe (Hamilton Co. Inc.) and incubated for another 2 hours. Then $5 \mu \mathrm{l}$ of a $5 \%$ eosin solution prepared in water (stain for dead cells) was added and after 10 minutes, $5 \mu$ l of buffered formalin ( $40 \%$ formaldehyde solution titrated with $\mathrm{KOH}$ to $\mathrm{pH} 7.2$ ) was added and the plates were incubated for 30 minutes. Finally, paraffin oil was added and the wells were covered with polystyrene planing slides $(45 \times 72 \mathrm{~mm}$, Lux, Miles Scientific, Div. Miles Laboratories Inc., Naporville, IL. 60566, U.S.A.). The plates were read under an inverted microscope. The reaction in each well was scored according to the percent of cells that had been killed.

\subsection{Cloning}

Nfld.M2 was cloned twice during the course of the experiment. The cloning was done by limiting dilution as described by Oi and Herzenberg (1980). The cells were counted and diluted to give 230 hybrids per $4.6 \mathrm{ml}$ of culture medium. To each of 36 wells of a 96 well flat-bottomed plate (Linbro Inc., subsidiary of Flow Labs.) was added $100 \mu \mathrm{l}$ of the diluted cell suspension to give 5 cells/well. An additional $4 \mathrm{ml}$ of culture medium was added to the 
remaining $1 \mathrm{ml}$ cell suspension and $100 \mu \mathrm{l}$ of this was added to another 36 wells to give 1 cell/well. To the remaining cell suspension was added $1.4 \mathrm{ml}$ of the culture medium and the last 24 wells were plated with $100 \mu$ l to give 0.5 cells/well. These plates were then incubated at $37^{\circ} \mathrm{C}$ in a humidified $\mathrm{CO}_{2}$ incubator. On day $3,100 \mu \mathrm{l}$ of fresh culture medium was added to each well and the plates were fed at 5 day intervals after that. Feeding was done by removing half of the supernatants from the wells with pasteur pipettes and replenishing them with fresh culture medium. When the cells were $50 \%$ confluent, the supernatants were tested for the presence of antibody by CDC (section 2.10). Wells found to be positive were transferred to 24 well plates (Linbro Inc.). When they again achieved $50 \%$ confluency, they were transferred to $50 \mathrm{ml}$ culture flasks (Falcon, Div. Becton, Dickinson \& Co., Oxnard, California 93030 U.S.A.).

\subsection{The plaque assay}

\subsubsection{The petri dish method}

$5 \times 10^{6}$ fluorescein labelled target cells were used per petri dish $(35 \times 10$ $\mathrm{mm}$, Falcon). In LP3 tubes (10.5 mm x $63.5 \mathrm{~mm}$, Victoria Gardens, Burgess Hill, Sussex) were placed, a) $10 \mu \mathrm{l}$ containing $5 \times 10^{6}$ labelled target cells, b) one of the following:

(i) $40 \mu \mathrm{l}$ of PBS, negative control, or 
(ii) $40 \mu \mathrm{l}$ of ALS (1/16 dilution), positive control, or

(iii) $40 \mu \mathrm{l}$ of supernatant at various dilutions from an overgrown culture of Nfld.M2, or

(iv) $10 \mu \mathrm{l}$ of Nfld.M2 hybridoma cells at various concentrations plus $30 \mu \mathrm{l}$ of PBS

c) $0.25 \mathrm{ml}$ of warm $\left(45^{\circ} \mathrm{C}\right) 2 \times$ BSS containing $0.2 \%$ DEAE-dextran (Sigma). The tubes were then placed in a $45^{\circ} \mathrm{C}$ waterbath and $0.25 \mathrm{ml}$ of warm $\left(45^{\circ} \mathrm{C}\right)$ 1.4\% agar (Bacto agar, Difco Labs., Detroit, Michigan, U.S.A.) was added to each. The cell suspension from each tube was mixed well and quickly poured into prewarmed petri dishes. When the agar solidified, the dishes were flooded with culture medium and incubated at $37^{\circ} \mathrm{C}$ in the dark as were all subsequent incubations. After two hours, the medium was poured off and the plates were flooded with rabbit complement (HLA-ABC complement) and incubated for another 2 hours. The complement was then poured off and the dishes were examined under epi-illumination in a Zeiss fluorescence microscope using an interference filter transmitting at $450-490 \mathrm{~nm}$, and a 520 barrier filter. The $10 \mathrm{x}$ ocular and the $6.3 \mathrm{x}$ objective lenses were found to be satisfactory.

\subsubsection{Slide method \#1}

This slide method was a modification of the method developed by Cunningham and Szenberg in 1968. 


\subsubsection{A. Assembling microchambers}

The chambers were prepared by placing strips of double-sided adhesive tape (12 mm wide) at both ends of a microscope slide $(75 \times 25 \mathrm{~mm}$, precleaned, plain) and one at the centre, thus dividing the free surface into two roughly equal areas. Coverslips $(22 \times 22 \mathrm{~mm})$ were pressed onto each area so that they stuck firmly. Each one thus produced a chamber that was approximately $22 \mathrm{x}$ $19 \times 0.1 \mathrm{~mm}$. The capacity of each chamber was approximately $40-45 \mu \mathrm{l}$ (Figure 1).

\subsubsection{B. The assay}

The assay was performed by the following procedure: In LP3 tubes were placed a) $10 \mu \mathrm{l}$ of $2 \times 10^{6}$ labelled target cells, b) $10 \mu \mathrm{l}$ of one of the following:

(i) PBS, negative control, or

(ii) Supernatant from an overgrown culture of Nfld.M2, positive control, or

(iii) Antibody-secreting cells at various concentrations

and c) $45 \mu \mathrm{l}$ of complement. The tubes were then placed in a $45^{\circ} \mathrm{C}$ waterbath and $20 \mu \mathrm{l}$ of warm $\left(45^{\circ} \mathrm{C}\right) 1.5 \%$ agar (prepared in water) containing $5 \mathrm{x}$ BSS and $0.5 \%$ DEAE-dextran was added to each. The cell suspension from each

*The error in the concentration of BSS was discovered after the thesis had been examined. The final concentration of BSS in the slides should have been $1 x$ and it was not. The cells did not appear to be unduly affected by the hypertonic environment. 


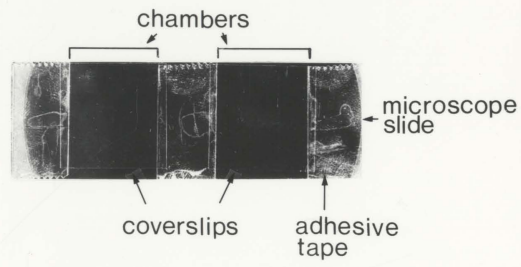

Figure 1: Slide method \#1

The two chambers on a microscope slide after assembly are shown. The chambers are filled with a pasteur pipette through the opening at the top or bottom. 
tube was then mixed well and quickly pipetted into the two chambers of a prewarmed slide with a pasteur pipette. One tube was used per slide. The slides were incubated at room temperature for two hours in the dark and then examined under a fluorescence microscope. When PI was incorporated in the assay to stain for dead cells, then $8 \mu \mathrm{l}(1 \mathrm{mg} \mathrm{PI} / \mathrm{ml}$ of PBS) was added to the cell mixtures and the volumes of target cells and antibody-secreting cells were cut in half. When antiserum was used in the experiment, then $5 \mu \mathrm{l}$ of antiserum was added to the cell mixtures.

\subsubsection{Slide method \#2}

\subsubsection{A. Assembling microchambers}

The microscope slides were prepared as usual with adhesive tape. The coverslips were lined with a water repellent vinyl sheet (Easy-on Brand 'Light Tack' Self-Adhesive obtained from a supermarket, designed for lining kitchen surfaces, paper documents, etc) and placed vinyl side down on the slides; this vinyl cover prevented the coverslips from adhering to the agar (Figure 2).

\subsubsection{B. The assay}

The assay was done by the following procedure: In LP3 tubes were placed a) $10 \mu \mathrm{l}$ containing $2 \times 10^{6}$ labelled target cells, b) $10 \mu \mathrm{l}$ of one of the following: 


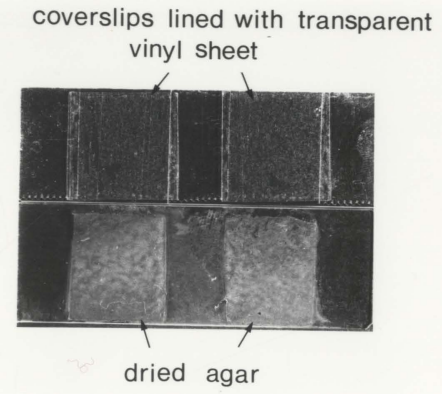

Figure 2: Slide method \#2

The photograph on the top illustrates the chambers with the coverslips lined with the transparent vinyl sheet in place. The photograph on the bottom shows the microscope slides after the removal of the coverslips and after the agar has been dried. 
(i) PBS, negative control, or

(ii) Supernatant from an overgrown culture of Nfld.M2, positive control, or

(iii) Antibody-secreting cells at various concentrations

and c) $8 \mu \mathrm{l}$ of PI. The tubes were then placed in a $45^{\circ} \mathrm{C}$ waterbath and $54 \mu \mathrm{l}$ of warm $\left(45^{\circ} \mathrm{C}\right) 1.4 \%$ agar (prepared in water) containing $1.5 \mathrm{x} \mathrm{BSS}^{*}$ with $0.15 \%$ DEAE-dextran was added to each. The cell suspension from each tube was mixed well and then pipetted into the two chambers of a prewarmed slide. After a few minutes, giving the agar time to solidify, the coverslips were gently removed taking care not to disturb the layers of agar on the slides. The slides were flooded with culture medium and incubated for two hours. All incubations were done at room temperature and in the dark. The medium was then poured off and the slides were flooded with complement (HLA-ABC or DR complement). After another two hours, the complement was poured off and the slides were dried with an electric hot air dryer resulting in permanent preparations (Figure 2). The slides were then examined under a fluorescence microscope or stored in the dark in microscope slide folders and examined at a later date. When antiserum was used, the slides were flooded with antiserum and incubated for two hours before the addition of complement. The rest of the procedure was the same as before.

refer to footnote on page 29. 


\subsubsection{Plaque size}

To measure plaque size, a grid containing 100 equal size squares within a large square was inserted into the eyepiece of the microscope. Using a stage micrometer, the squares on this grid were calibrated and found to measure 0.8 $\mathrm{mm}$ on each side, when the microscope was set up with a $6.3 \mathrm{x}$ objective and a 12.5x ocular. Plaques were then superimposed on the grid, one at a time, and their diameters measured in relation to the squares on the grid. Some $40-50$ plaque diameters were measured. In some experiments, both plaque size and $\%$ lysis were scored (Tables 4 and 6 ). In these cases, mainly confluent plaques were present, but the outline of the plaques was often sufficiently preserved for approximate diameters to be scored. 


\section{CHAPTER 3}

\section{RESULTS}

The results are described under five main headings, 3.1-3.5, and are given in more or less chronological order as the technique was developed and evaluated. After describing the principle in section 3.1, a series of exploratory experiments is described in section 3.2 in which labelled target cells were plated in petri dishes. In these experiments, attempts were made to lyse the target cells with anti-lymphocyte serum, monoclonal antibodies, and lastly hybridoma cells. The second set of experiments, described under section 3.3, reveal the trial and error development of a plaque method done using microscope slides and coverslips to enclose small chambers. A modification of this method using two dyes was introduced quite late and the results are given in section 3.3.8. Due to an unexpectedly low yield of plaques, some further experiments were done to try to trace the possible cause(s) of damage to the antibody-forming cells during processing. Under section 3.4, a second version of the slide method is described in which the coverslips were removed from the agar-bound cell suspension after the agar had solidified, so that a second antibody and complement could be added directly to the surface of the preparation after a period of incubation of the target cells with the hybridoma cells. Experimental modifications, at this point, including the drying procedure proved to be advantageous. In a final section, 3.5 , the technique was put to 
use to answer questions concerning the need for recloning of Nfld.M2, the possibility of adapting the technique to detect human antibody-secreting cells (ASC), and concerning the use of this technique to detect plaques with a mouse hybridoma producing a non-complement fixing, IgG1 antibody.

\subsection{Principle}

Carboxyfluorescein diacetate (CFDA) formed the basis of the plaque assay. CFDA penetrates most mammalian cells and, upon hydrolysis by the esterases within the cell, is converted to fluorescein (Rotman and Papermaster, 1966) which fluoresces green under a fluorescence microscope. Here, EpsteinBarr virus (EBV)-transformed cells which were used as targets were labelled with CFDA. The procedure is described in materials and methods, section 2.2.2. The cells remained alive and intact after this procedure. The principle behind the plaque assay was that upon lysis, the target cells would release their fluorescein and become invisible. This would result in lytic plaques that could be seen as clear areas surrounded by a lawn of green fluorescing cells. During the course of the experiments, the use of another stain, propidium iodide (PI), to label dead cells was started. Cells stained with PI appear orange-red under the same microscopic conditions. The plaques could then be visualized as orange-red areas surrounded by green fluorescing cells. This two stain method was originally introduced by Bruning, Claas, Kardol, Lansbergen, Naipal and Tanke in 1982 for the purpose of automated reading of HLA typ- 
ing plates and for screening of antibodies with the microcytotoxicity assay.

\subsection{The petri dish method}

The first experiments to develop a plaque method were done in petri dishes. The technical details are described in materials and methods, section 2.12.1. Before looking for plaques, it was necessary to establish an optimal concentration for the target cells and to show that lysis of these target cells did indeed result in release of fluorescein and consequently fading of the target cells $(3.2 .1,3.2 .2,3.2 .3)$

\subsubsection{Concentration of target cells}

The concentration of target cells (C.H.M.) was varied from $1 \times 10^{6}$ to $1 \mathrm{x}$ $10^{8}$ per petri dish in order to determine the concentration that gave the most confluent layer with an even distribution of cells. The petri dishes were set up without antibody and complement. It was found that high concentrations of cells gave a very dense layer of cells and, in some areas, clumping was also observed. Low concentrations of cells resulted in a layer which was very sparsely populated with gaps between cells. The optimal density of target cells for the petri dish method was determined to be $5 \times 10^{6}$ per petri dish. This gave an appearance similar to figure 3 (no photographs were taken for the petri dish method) and this concentration was used in subsequent experiments. 


\subsubsection{Experiments with anti-lymphocyte serum}

The aim of these experiments was to observe target cell lysis and to determine if cell lysis was sufficiently visible to be detectable in a plaque. Since earlier attempts to produce plaques with Nfld.M2 hybrids had been unsuccessful (data not shown), it was necessary to start at a very basic level. Antilymphocyte serum (ALS) was used because it is known to be cytotoxic for lymphocytes in the presence of complement. In three separate experiments, serial dilutions of ALS, ranging from undiluted to $1 / 128$ were added to petri dishes, along with target cells (C.H.M.). The dishes were flooded with complement after incubation. It was found that ALS did indeed lyse the target cells and in a dose dependent manner, with dilutions below $1 / 16$ giving $95-100 \%$ lysis (similar to figure 4) and dilutions above that giving progressively less lysis until, at $1 / 64$, the dish looked no different from an untreated control. The lysed cells were still visible under the fluorescence microscope and looked like pale 'ghostly' versions of the previously brightly fluorescing cells.

\subsubsection{Experiments with supernatants from Nfld.M2 cultures}

Since the cytotoxicity of ALS was clearly demonstrated in the previous experiments, it was important to see if Nfld.M2 antibody was similarly cytotoxic. Supernatant from an overgrown Nfld.M2 culture was known to be cytotoxic in complement dependent cytotoxicity (CDC), in a regular cytotoxicity assay performed in Terasaki plates (materials and methods, section 2.10) with 
a titre of $1 / 128\left(1 \mu \mathrm{l}\right.$ of supernatant was used per $2 \times 10^{3}$ cells per well). Hence, this supernatant was similarly titred in the petri dish method to determine if the results were comparable. In two separate experiments, petri dishes were set up with serial dilutions of supernatant ranging from undiluted to 1/128, plus target cells (C.H.M.). Complement was added after incubation. The supernatant was found to be cytotoxic with a titre of $1 / 8$ with $95-100 \%$ lysis ( $40 \mu \mathrm{l}$ of supernatant was used per $5 \times 10^{6}$ cells). Taking into consideration the number of target cells and the volume of supernatant used for each method, the two methods appeared to be of similar sensitivity.

\subsubsection{Experiments with hybridoma cells from Nfld.M2 cultures}

With the cytotoxicity of Nfld.M2 antibody established, an attempt was once again made to produce plaques, using Nfld.M2 hybridoma cells. In a series of experiments, the petri dishes were set up with concentrations of hybridoma cells ranging from $1 \times 10^{3}$ to $5 \times 10^{6}$ per petri dish plus target cells (C.H.M.). Complement was added after incubation. The results are summarized in table 2. At a ratio of 1:1 of target cells to hybridoma cells, complete lysis was seen and as the concentration of hybridoma cells decreased, so did target cell lysis. At hybridoma cell concentrations less than or equal to $1 \times 10^{4}$ per petri dish, no lysis was seen. In all these dishes, plaques were not detectable. The interpretation of these results was that perhaps the target cell layer was too thick so that any small area of lysis was probably obscured by intact 


\section{Table 2}

Degree of lysis of target cells with decreasing concentrations of Nfld.M2 hybridoma cells (petri dish method)

\begin{tabular}{|c|c|}
\hline Concentration of Hybridoma Cells & Degree of Lysis* \\
\hline $5 \times 10^{6}$ & ++++ \\
$1 \times 10^{6}$ & $++(+)$ \\
$5 \times 10^{5}$ & ++ \\
$1 \times 10^{5}$ & + \\
$5 \times 10^{4}$ & $(+)$ \\
$1 \times 10^{4}$ & - \\
$5 \times 10^{3}$ & - \\
$1 \times 10^{3}$ & - \\
\hline
\end{tabular}

$\begin{array}{ll}*++++ & \text { approx. } 95-100 \% \text { target cell lysis } \\ +++(+) & \text { approx. } 85-90 \% \text { target cell lysis } \\ +++ & \text { approx. } 75-80 \% \text { target cell lysis } \\ ++(+) & \text { approx. } 60-70 \% \text { target cell lysis } \\ ++ & \text { approx. } 50-55 \% \text { target cell lysis } \\ +(+) & \text { approx. } 35-45 \% \text { target cell lysis } \\ + & \text { approx. } 20-30 \% \text { target cell lysis } \\ ++ & \text { approx. 10-15\% target cell lysis } \\ + & \text { less than } 10 \% \text { target cell lysis }\end{array}$


cells present above and/or below the lysed cells. The approach that seemed appropriate to overcome this was to use microscope slides instead of petri dishes so that a thinner layer of target cells could be obtained.

\subsection{Slide method \#1}

The slide method was a modification of the method developed by Cunningham and Szenberg in 1968. It was hoped that these chambers of defined depth would allow thinner layers of target cells to be formed, in which lysis would be more easily visible.

\subsubsection{Capacity of the chambers}

The chambers were prepared as described in materials and methods, section 2.12.2A. Measured volumes of liquid were then delivered into the chambers and the capacity of each chamber was determined to be $40-45 \mu \mathrm{l}$ giving a slide capacity of approximately $80-90 \mu \mathrm{l}$.

\subsubsection{Concentration of target cells}

The optimal target cell concentration had to be determined again for this method. The slides were set up with concentrations of target cells (C.H.M.) ranging from $1 \times 10^{5}$ to $1 \times 10^{7}$ per chamber and without antibody or complement. A monolayer of target cells was obtained and $1 \times 10^{6}$ was determined to be the optimal target cell density per chamber of a slide (figure 3 ). 


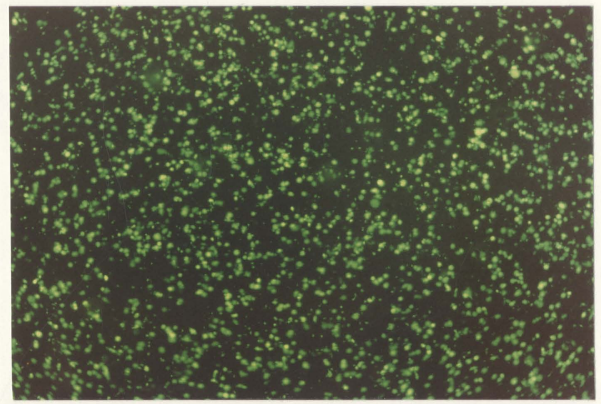

Figure 3: Negative control, slide method \#1

Photomicrograph of a monolayer of fluorescein-stained target cells (C.H.M.) obtained with a density of $1 \times 10^{6}$ cells per chamber. Magnification: $63 \mathrm{x}$ 


\subsubsection{Complement volume}

Since the capacity of each chamber was limited, it was necessary to determine the minimum volume of complement required for target cell lysis. In two separate experiments, the slides (i.e. two chambers) were set up with volumes of complement ranging from $5 \mu \mathrm{l}$ to $65 \mu \mathrm{l}$ per slide along with target cells (C.H.M.) and Nfld.M2 antibody. Little or no lysis was found in the slides containing less than $30 \mu \mathrm{l}$ of complement. In slides containing $40 \mu \mathrm{l}$ or more of complement, $95-100 \%$ lysis was observed. Hence, $45 \mu \mathrm{l}$ of complement per slide was used in subsequent experiments.

\subsubsection{Incorporation of agar}

The slide method was originally set up as a liquid monolayer. This was later modified to a semi-solid monolayer, because it was observed that when the slides were set up with various concentrations of Nfld.M2 hybridoma cells ranging from $5 \times 10^{2}$ to $2 \times 10^{5}$, target cells (C.H.M.) and complement and incubated at $37^{\circ} \mathrm{C}$, the target cells became agglutinated. This made the detection of plaques impossible. Since agglutination was not seen in the negative controls, it was attributed to the fact that the antibody-coated target cells which were in fluid suspension, moved about, thus coming into contact with each other and resulting in agglutination. It was thought that if agar was incorporated in the assay, it would provide a semi-solid support for the target cells, and thus inhibit their motility. 
It was necessary to determine the concentration of agar that would ensure easy filling of the chambers and an even distribution of cells without clumping. In four separate experiments, slides were set up with concentrations of agar ranging from $0.1 \%$ to $1 \%$ per slide, along with target cells (C.H.M.), Nfld.M2 hybridoma cells and complement. It was found that a final concentration of agar in the cell mixtures of approximately $0.3 \%$ per slide was sufficient to allow the cell mixtures to be delivered easily into the chambers and to produce a satisfactory monolayer of target cells. At concentrations lower than $0.3 \%$, the agar was too fluid and movement of the target cells could be observed under the microscope if the slides were disturbed in any way while viewing. One problem that was encountered with the use of agar was that if the slides were cold, the agar would set while the chambers were being filled and this resulted in uneven monolayers. Pre-warming the slides eliminated this problem.

\subsubsection{Non-specific leaking of fluorescein}

It was observed in the slide method, in both the negative controls (no Nfld.M2 hybridoma cells added) and the experimental slides (with Nfld.M2 hybridoma cells), that the live target cells were spontaneously losing some of their fluorescence and were fading during the incubation at $37^{\circ} \mathrm{C}$. This was not noticed in the petri dish method, perhaps due to the multiple target cell layers. Spontaneous leaking out of fluorescein from lymphocytes has been 
observed by other investigators (Bodmer, Tripp and Bodmer, 1967). These authors suggested that this non-specific leaking out of fluorescein is an energy dependent process, probably connected with an active transport mechanism. They showed that this leaking at $37^{\circ} \mathrm{C}$ could be prevented by the use of metabolic inhibitors such as potassium cyanate and sodium azide.

If the leaking out of fluorescein involves an active transport mechanism which requires energy, it was thought that incubating the slides at a lower temperature, such as room temperature, might slow down the process, and hence reduce or completely eliminate this loss of fluorescein from target cells. In two separate experiments, two sets of slides were set up with target cells (C.H.M.), Nfld.M2 hybridoma cells and complement. One set of slides was incubated at $37^{\circ} \mathrm{C}$ and one at room temperature. At room temperature, the loss of fluorescein was considerably reduced. Also, fortunately, no appreciable difference was observed in the degree of complement dependent lysis between the slides incubated at $37^{\circ} \mathrm{C}$ and the ones incubated at room temperature. Therefore, all the subsequent incubations were done at room temperature.

\subsubsection{Experiments using various target cells with Nfld.M2 antibody}

The following experiments were done to ensure that the observed cytotoxicity of Nfld.M2 antibody was specific for cells having the phenotype HLA-A2 and A28 and not due to some non-specific factor present in Nfld.M2 cultures or else some artefact produced by the plaque assay that resulted in target cell 
lysis. In two separate experiments, various target cells of different HLA phenotypes (table 1) were set up on slides along with complement and supernatant from an overgrown culture of Nfld.M2. As can be seen from table 3, in all the slides containing HLA-A2 positive target cells, lysis was observed, whereas in the ones containing HLA-A2 negative target cells, no lysis was seen. In another two experiments, Nfld.M2 hybridoma cells were used instead of supernatant. Slides were set up with $1 \times 10^{6}$ hybridoma cells per slide together with the various target cells and complement. The results were qualitatively identical, with the hybridoma cells leading to $95-100 \%$ lysis only when the target cells expressed A2 or A28.

\subsubsection{Experiments with hybridoma cells from Nfld.M2 cultures}

After optimizing all the parameters of the slide method, an attempt was once again made to produce plaques with Nfld.M2 hybridoma cells. The purpose of these experiments was to see if individual plaques could be produced with low concentrations of hybridoma cells. In a series of experiments, concentrations of hybridoma cells, ranging from $5 \times 10^{2}$ to $1 \times 10^{6}$ per chamber were set up on slides along with target cells (C.H.M.) and complement. It was found that at a concentration of hybridoma cells of $1 \times 10^{6}$ per chamber, complete lysis (95-100\%) was observed, whereas definite but confluent plaques were seen at concentrations of $1 \times 10^{5}$ per chamber. These are shown in figures 4 and 5 respectively. At concentrations lower than $1 \times 10^{5}$, individual plaques 


\section{Table 3}

\section{HLA specificity of Nfld.M2 demonstrated as} lysis of target cells using slide method \#1

\begin{tabular}{|c|c|c|}
\hline Target Cell Line & HLA-A Phenotype & Degree of Lysis* \\
\hline \hline E.A. & 1,2 & ++++ \\
\hline B.C. & 1,2 & ++++ \\
\hline D.C. & 3 & - \\
\hline E.C. & 1,3 & - \\
\hline M.C. & 1,24 & - \\
\hline K.H. & 1,2 & ++++ \\
\hline C.A.K. & 1,24 & - \\
\hline C.H.M. & 1,2 & ++++ \\
\hline L.R. & $3, w 24$ & - \\
\hline T.P. & 2,28 & ++++ \\
\hline
\end{tabular}

* $++++\quad$ approx. $95-100 \%$ target cell lysis less than $10 \%$ target cell lysis 


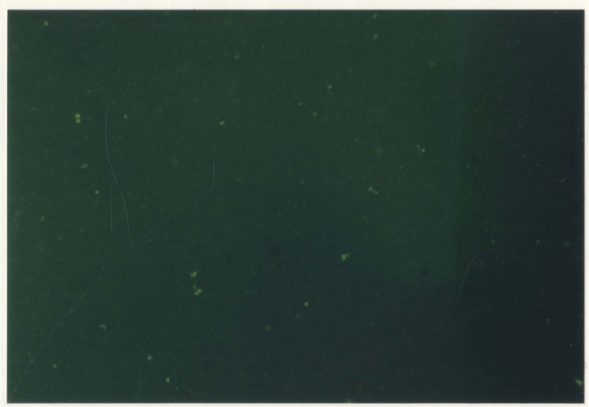

Figure 4: Total target cell lysis, slide method \#1

Approximately $95 \%$ lysis of the target cells by Nfld.M2 hybridoma cells at a concentration of $1 \times 10^{6}$ cells per chamber is shown. The lysed cells are faintly visible in the photomicrograph. Magnification: 63x. 


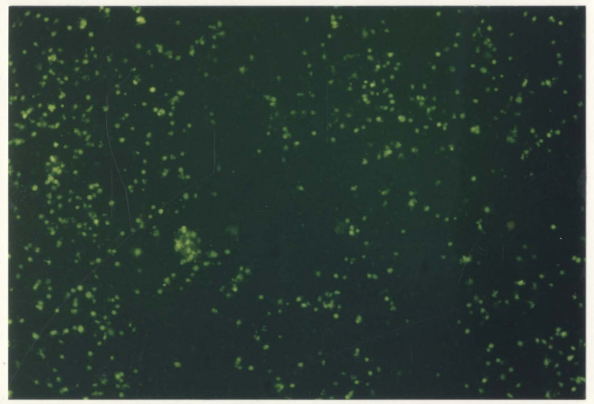

Figure 5: Confluent plaques, slide method \#1

Confluent plaques made by Nfld.M2 hybridoma cells at a concentration of $1 \mathrm{x}$ $10^{5}$ cells per chamber are shown. Magnification: $63 \mathrm{x}$. 
were observed (figure 6). The sizes of the plaques usually ranged from 0.1-0.4 $\mathrm{mm}$ in diameter. Plaque sizes of $0.5-0.6 \mathrm{~mm}$ were also observed but very rarely and they were thought to probably result from the secretion of antibody by two or more neighbouring plaque-forming cells (PFC). Although, the bigger plaques (0.3-0.4 mm) were clear and easily identified (figure 6,) the smaller ones (0.1-0.2 $\mathrm{mm}$ ) were hard to distinguish from the normal background variation in the distribution of the target cells. In order to overcome this problem, the use of another stain, PI, was started. It was hoped that PI would enhance the appearance of small plaques in that they would stand out better from the background of target cells.

\subsubsection{Addition of Propidium Iodide}

These experiments were set up in order to determine the concentration of PI that gave good staining of dead cells. In three separate experiments, slides were set up with volumes of PI ranging from $1 \mu \mathrm{l}$ to $10 \mu \mathrm{l}$ per slide at a concentration of $1 \mathrm{mg} / \mathrm{ml}$ along with target cells (C.H.M.), Nfld.M2 hybridoma cells and complement. It was found that about 8-10 ul of PI per slide gave good staining of dead cells. Below 8 ul, the staining was too faint. Therefore, $8 \mu \mathrm{l}$ per slide was used in subsequent experiments. The addition of PI did indeed make it easier to distinguish small plaques which were usually clear and distinct provided the background of target cells was even and of high viability and the PI staining was good. If the viability of the target cells was low, then 


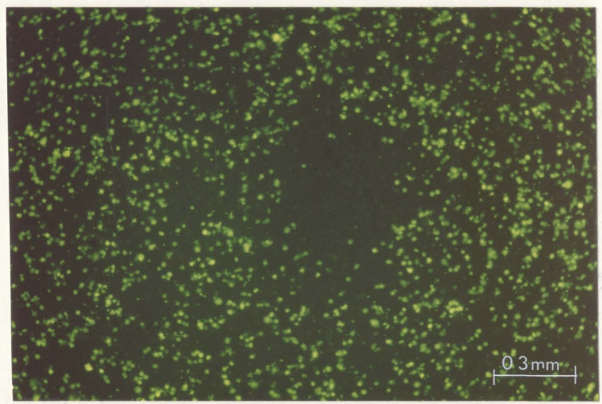

Figure 6: Single plaque, slide method \#1

A single plaque made by a Nfld.M2 hybridoma cell at a concentration of $1 \mathrm{x}$ $10^{4}$ cells per chamber is shown. Magnification: $63 x$. 
the high background of PI-stained cells made it difficult to detect small plaques. The plaques ranged from $\mathbf{0 . 1 - 0 . 4} \mathrm{mm}$ in diameter and usually contained 15 or more dead cells depending on the size of the plaque. There was usually no intervening live cell visible at the centre of a plaque. The plaques observed were similar to those shown in figures 7 and 8 which are the result of slide method \#2.

\subsubsection{Number of Nfld.M2 hybridoma cells versus number of plaques}

The purpose of this experiment was to see if the number of plaques obtained was proportional to the number of Nfld.M2 hybridoma cells plated. In a series of experiments, slides were set up with concentrations of hybridoma cells ranging from $6.3 \times 10^{2}$ to $8 \times 10^{4}$ per chamber along with target cells (C.H.M.), complement and PI. The plaques were subsequently counted by scanning entire chambers, using a $6.3 \mathrm{x}$ objective. This was relatively fast and easy, taking 2-5 minutes for an average plaque density. Up to approximately 1500 plaques per chamber could be counted with accuracy. A higher number resulted in confluency and consequently less accuracy in counting. When the concentration of hybridoma cells was plotted against the number of plaques, a straight line relationship was observed (figure 9). This experiment was repeated a number of times and it was found that although a straight line relationship was observed each time, the slope of the graphs varied, that is, the number of plaques obtained for the same number of hybridoma cells varied 


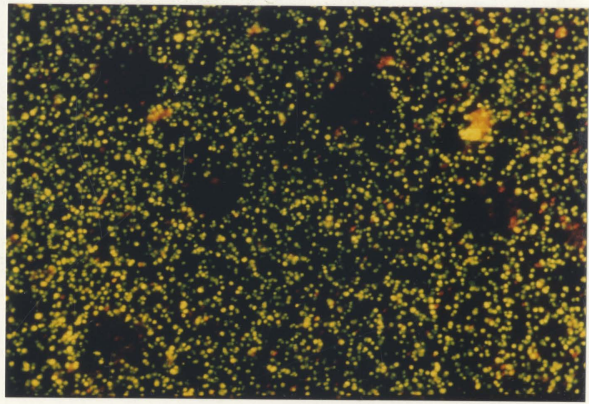

Figure 7: PI staining of dead cells, slide method \#2

Five plaques made by Nfld.M2 hybridoma cells at a concentration of $5 \times 10^{3}$ cells per chamber, containing PI-stained dead cells (red) are shown. This photomicrograph illustrates the high viability of the background of target cells. Magnification: $63 x$. 


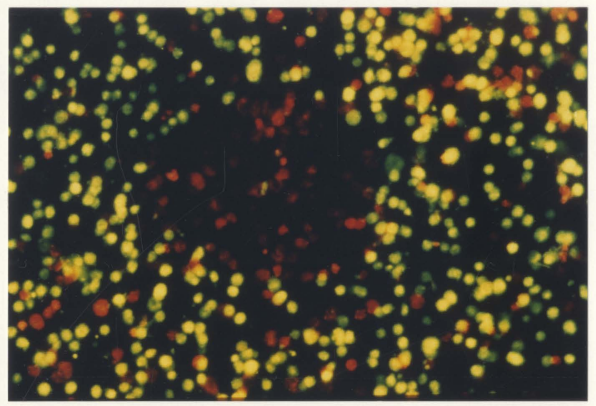

Figure 8: PI staining of dead cells, slide method \#2

The PI-stained dead cells in the center of the plaque are more clearly visible because of the high magnification $(160 \mathrm{x})$. 


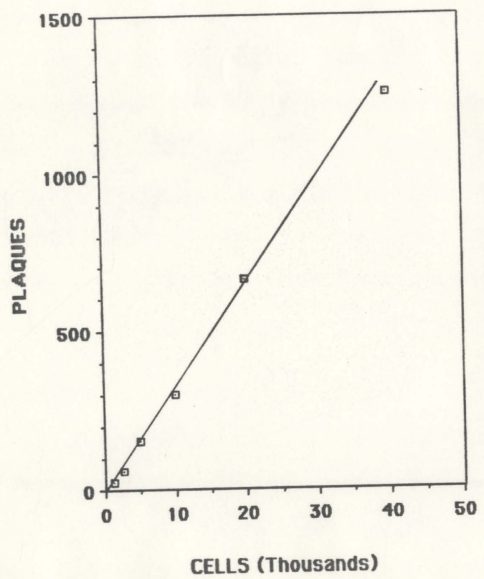

Figure 9: Number of plaques formed as a function of number of hybridoma cells plated (slide method \#1).

Graph showing the number of plaques obtained in one experiment versus the number of Nfld.M2 hybridoma cells plated. 
from day to day.

Another unexpected finding was that the number of plaques observed was considerably less than the number of hybridoma cells plated (usually less than $5 \%$ ). This discrepancy could have been due to the experimental manipulations which may have been altering the viability or function of the hybrids, and in particular, the warming to $45^{\circ} \mathrm{C}$ could have been potentially damaging, although the target cells usually appeared to be of high viability. In order to investigate this problem, two sets of experiments were performed; one to investigate the question of viability after exposure to $45^{\circ} \mathrm{C}$ and the other to investigate the effect of $45^{\circ} \mathrm{C}$ on antibody secretion.

\subsubsection{A. Effect of $45^{\circ} \mathrm{C}$ on the viability of hybridoma cells}

In this experiment, several tubes containing the same number of Nfld.M2 hybridoma cells were exposed to $45^{\circ} \mathrm{C}$ for various lengths of time ranging from 0 to 60 seconds and the viability was subsequently determined by the trypan blue exclusion test as described in materials and methods, section 2.6. It was found that the viability decreased by approximately $16 \%$ from 0 seconds to 60 seconds. From 0 to 15 seconds, there was a decrease in viability of approximately $5 \%$. In the actual experiments, the hybridoma cells are exposed to $45{ }^{\circ} \mathrm{C}$ for approximately $10-15$ seconds. Therefore, the effect of this temperature on viability appeared to be minimal.

\subsubsection{B. Effect of $45^{\circ} \mathrm{C}$ on antibody secretion}


In this experiment, Nfld.M2 hybridoma cells were washed twice and $10 \mu \mathrm{l}$ aliquots containing $5 \times 10^{5}$ cells were placed in several tubes. One tube was spun down immediately and the supernatant removed. The other tubes were exposed to $45^{\circ} \mathrm{C}$ for various lengths of time ranging from 0 seconds to 60 seconds and were then incubated for two hours and centrifuged. The supernatant from each tube was set up on slides along with target cells (C.H.M.), complement and PI. It was found that the supernatant removed from the tube that was centrifuged immediately did not give any lysis. The other tubes all gave approximately $70-80 \%$ target cell lysis. Therefore, antibody secretion did not seem to be unduly affected by exposure of the hybridoma cells to $45^{\circ} \mathrm{C}$ for these periods of time.

\subsubsection{Effect of anti-immunoglobulin antiserum (slide method \#1)}

The purpose of these experiments was to determine if the addition of antiserum would facilitate target cell lysis by enhancing the complement fixing ability of Nfld.M2 antibody and hence increase the number of plaques. In a series of experiments, slides were set up with serial dilutions of antiserum (rabbit anti-mouse IgG, IgA and IgM) ranging from $1 / 25$ to $1 / 3200$ per chamber together with target cells (C.H.M.), Nfld.M2 hybridoma cells ranging from $5 \mathrm{x}$ $10^{2}$ to $1 \times 10^{5}$, complement and PI. The effect shown in table 4 was observed at a hybridoma cell concentration of $1 \times 10^{4}$ per chamber. Similar results were obtained at hybridoma cell concentrations ranging from $1 \times 10^{4}$ to $5 \times 10^{4}$ per 


\section{Table 4}

\section{Effect of serial dilutions of anti-Ig antiserum (As) on the number and size of plaques formed (slide method \#1)}

\begin{tabular}{|c|c|c|}
\hline Dilution of $\mathrm{As}^{\mathrm{a}}$ & Degree of Lysis & Plaque Size $^{\mathrm{c}}$ \\
\hline \hline 0 & ++ & $0.1-0.3 \mathrm{~mm}$ \\
\hline $1 / 25$ & - & \\
\hline $1 / 50$ & $(+)$ & \\
\hline $1 / 100$ & $+(+)$ & $0.1-0.2 \mathrm{~mm}$ \\
\hline $1 / 200$ & ++ & $0.1-0.3 \mathrm{~mm}$ \\
\hline $1 / 400$ & +++ & confluent \\
\hline $1 / 800$ & +++ & confluent \\
\hline $1 / 1600$ & ++ & $0.2-0.4 \mathrm{~mm}$ \\
\hline $1 / 3200$ & + & $0.1-0.2 \mathrm{~mm}$ \\
\hline
\end{tabular}

a antiserum used was rabbit anti-mouse IgG, IgA, IgM $(\mathrm{H}+\mathrm{L})$.

b Nfld.M2 hybridoma cells were used at a concentration of $1 \times 10^{4}$ cells per chamber of a slide.

$++++\quad$ approx. $95-100 \%$ target cell lysis

$+++(+) \quad$ approx. $85-90 \%$ target cell lysis

$+++\quad$ approx. $75-80 \%$ target cell lysis

$++(+) \quad$ approx. $60-70 \%$ target cell lysis

$++\quad$ approx. $50-55 \%$ target cell lysis

$+(+) \quad$ approx. $35-45 \%$ target cell lysis

$+\quad$ approx. $20-30 \%$ target cell lysis

(+) approx. 10-15\% target cell lysis

- less than $10 \%$ target cell lysis

${ }^{c}$ some plaque sizes are not given because either there were no plaques present or they were confluent. 
chamber. At these cell concentrations, many plaques, although not confluent, were observed without the addition of antiserum. The addition of certain dilutions of antiserum (1/400-1/800) resulted in the plaques becoming confluent. At cell concentrations higher than $5 \times 10^{4}$ per chamber, the plaques were confluent without the addition of antiserum, therefore, the effect of antiserum could not be determined. At cell concentrations lower than $1 \times 10^{4}$, few plaques were observed without the addition of antiserum and the addition of antiserum did not have any measurable effect. An inhibitory effect was observed with high concentrations of antiserum at all cell concentrations. The hybridoma cell concentrations at which an effect could be observed by the addition of antiserum varied from assay to assay depending on the number of PFC present per number of hybridoma cells plated.

In these experiments the anti-Ig was present right from the start and therefore, as soon as the antibody was secreted, the interaction with anti-Ig began. The inhibition effect may be due to the fact that the anti-Ig, which was present in excess, formed immune complexes with the secreted Ig near the PFC, thus inhibiting its diffusion towards the target cells. The enhanced target cell lysis seen at certain hybridoma cell concentrations could be due to the fact that the PFC, which were present at high concentrations, tended to be at close proximity to each other. Therefore, the secreted antibody, present at high concentrations, probably formed soluble complexes with the anti-Ig (when optimally diluted) near the PFC and diffused towards the target cells where 
the Ig-anti-Ig complexes activated the complement and caused target cell lysis. It was thought that if anti-Ig was added later as in a classical indirect system, then this problem would be avoided because the secreted antibody would have a chance to bind to the target cells before the addition of anti-Ig. However, since experiments had, up to this point, been done in closed chambers, this modification could not be made without altering the entire technique. Such a modification is described in the next section.

\subsection{Slide method \#2}

Slide method \#2 was a modification of method \#1. It was devised so that anti-Ig could be added after the hybridoma cells had been incubated with the target cells.

\subsection{A. Lining of the coverslips}

In order to add the anti-Ig later, the coverslips had to be removed so that the surface of the agar layer could be exposed. Initially, an attempt was made to remove the coverslips after setting up the slides in the usual way. This did not work because the agar tended to adhere to the coverslips and any attempt at removing the coverslips resulted in tearing of the agar. It appeared necessary to line the coverslips with something that would prevent the agar from adhering to them. A transparent vinyl, self-adhesive sheet which was originally designed for covering kitchen surfaces, important documents, etc. was used for this purpose. This sheet was cut in squares slightly larger than the 
coverslips. The coverslips were then placed on the adhesive side of each square which was then trimmed to the size of the coverslip. The microscope slides were assembled as usual and the lined coverslips were placed vinyl side down on the slides. The slides were then set up and after giving the agar sufficient time to solidify, the coverslips were gently removed. Although the coverslips came off nicely, without tearing the agar, the agar layer was too loose and easily deformable and tended to come off the slides when the slides were flooded with medium. The concentration of agar was evidently too low and had to be increased. In a series of experiments, done to determine the appropriate concentration, slides were set up with concentrations of agar ranging from $0.4 \%$ to $2 \%$ per slide plus target cells (C.H.M.). After giving the agar time to solidify, the coverslips were removed. It was found that a final concentration of agar of approximately $0.8 \%$ per slide formed a nice layer that did not come off the slides after the coverslips were removed and the slides were flooded with medium.

\subsection{B. The drying procedure}

A hot air dryer was used to dry the agar on the slides after the final incubation. It was found that this drying procedure did not affect the fluorescence in any way. In fact, this modification has several advantages over the original slide method. One disadvantage of slide method \#1 was that quenching of the fluorescence would occur if the slides were examined for too long or at a high 
magnification, or if they were left overnight. This was inconvenient, especially if repeated examination of a slide was necessary, for example, when determining the diameters of the plaques. With this new method, the preparations were found to be permanent and plaques could be examined repeatedly, under bright illumination, with virtually no quenching and no detectable deterioration. This was an advantage since the slides could be looked at any time, long after the conclusion of the experiments. They could be stored easily in the dark in a slide box.

\subsubsection{Complement titration}

In order to avoid waste of complement by flooding the slides with needlessly high concentrations, complement was titred out in two separate experiments. Slides were set up with target cells (C.H.M.), Nfld.M2 hybridoma cells and PI. Serial dilutions of complement ranging from undiluted to $1 / 128$ per slide were added after incubation. The complement titred out at 1/4 and this dilution was used in subsequent experiments.

\subsubsection{Number of hybridoma cells versus number of plaques}

As for slide method \#1 (section 3.3.9), the relationship between the number of hybridoma cells plated and plaques formed was determined for slide method \#2. In three separate experiments, the slides were set up with target cells (C.H.M.), recloned Nfld.M2 hybridoma cells ranging from $6.3 \times 10^{2}$ to 8 x $10^{4}$ per chamber and PI. Complement was added after incubation. The 
plaques were subsequently counted and plotted against the number of hybridoma cells (this data was taken from the cloning experiment, clone 1 at day 13, section 3.5.1, figure 11a). A straight line relationship was observed as shown in figure 10. As for slide method \#1, there was a daily variation in the slope of the graph i.e. the percent of hybridoma cells which were actually secreting antibody was not constant.

\subsubsection{Comparison of slide method \#1 with slide method \#2}

The two slide methods were set up in parallel to compare their sensitivity in terms of detecting PFC. In three separate experiments, the two methods were set up with target cells (C.H.M.), Nfld.M2 hybridoma cells ranging from $6.3 \times 10^{2}$ to $8 \times 10^{4}$ per chamber, complement and PI. The total incubation time for both methods was the same. The plaques were subsequently counted and calculated to give plaques $/ 5000$ hybridoma cells. The results are summarized in table 5. It was found that slide method \#2 was approximately 5-10x more sensitive than slide method \#1. In the three experiments, on an average, the ratio of PFC for slide method \#1 to slide method \#2 was 1:4.8, 1:4.7, $1: 10.2$, respectively.

\subsubsection{Effect of anti-immunoglobulin antiserum (slide method \#2)}

In a series of experiments, the slides were set up with target cells (C.H.M.), Nfld.M2 hybridoma cells ranging from $5 \times 10^{2}$ to $1 \times 10^{5}$ per chamber and PI. After incubation, the slides were flooded with serial dilutions 


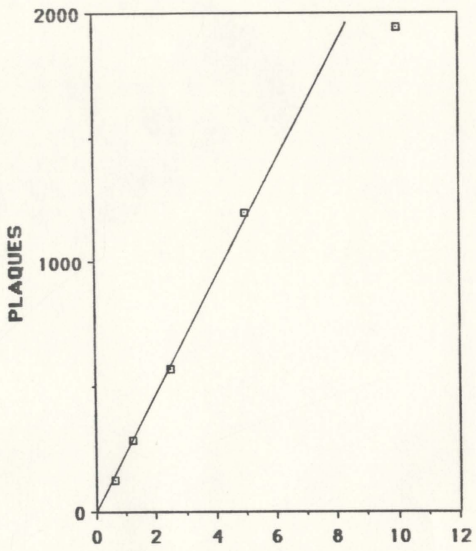

CELLS (Thousands)

Figure 10: Number of plaques formed as a function of number of hybridoma cells plated (slide method \#2)

Graph showing the number of plaques obtained in one experiment versus the number of Nfld.M2 hybridoma cells plated. 


\section{Table 5}

The number of plaques formed with Nfld.M2 hybridoma cells are compared for slide method \#1 and method \#2

\begin{tabular}{|c|c|c|}
\hline \multirow{2}{*}{ Experiment \# } & \multicolumn{2}{|c|}{ Plaques/5000 Hybridoma Cells } \\
\cline { 2 - 3 } & Method \#1 & Method \#2 \\
\hline 1 & 11 & 53 \\
\hline 2 & 17 & 80 \\
\hline 3 & 27 & 275 \\
\hline
\end{tabular}


of rabbit anti-mouse IgG, IgA and IgM ranging from 1/25 to $1 / 3200$ per slide. Complement was added after incubation. When the slides were examined, no plaques were seen in the slides to which antiserum had been added. In subsequent experiments, the antiserum was diluted from $1 / 200$ to $1 / 3,246,800$ and the results are summarized in table 6 . As for method \#1, a prozone effect and an optimal concentration ranging from $1 / 409,600$ to $1 / 819,200$ was observed and only at certain cell concentrations. The results shown in table 6 were observed at a hybridoma cell concentration of $5 \times 10^{3}$ cells per chamber. Similar results were obtained at hybridoma cell concentrations ranging from $5 \mathrm{x}$ $10^{3}$ to $2 \times 10^{4}$ per chamber and this was subject to variation from assay to assay as for method \#1. Therefore, adding the antiserum after prior incubation of the slides was not an improvement over adding it at initial preparation of the slides. The extraordinarily high dilutions needed to produce an enhancing effect and the possible mechanism for the prozone effect are considered later in the 'discussion' section.

\subsection{Some applications of the plaque assay}

\subsubsection{Cloning of Nfld.M2 hybrids}

Nfld.M2 hybridoma cells had been cloned twice during the early stages of the experiments but not since then. Therefore, there was a possibility that a majority of the hybridoma cells may have stopped producing antibody which could explain the low number of PFC obtained with this plaque assay. The 


\section{Table 6}

\section{Effect of serial dilutions of anti-Ig antiserum (As) on the number and size of plaques formed (slide method \#2)}

\begin{tabular}{|c|c|c|}
\hline Dilution of $\mathrm{As}^{3}$ & Degree of Lysis & Plaque Size \\
\hline \hline 0 & ++ & $0.1-0.2 \mathrm{~mm}$ \\
\hline $1 / 200$ & $(+)$ & \\
\hline $1 / 800$ & $(+)$ & \\
\hline $1 / 1600$ & $(+)$ & \\
\hline $1 / 3200$ & $(+)$ & $0.1-0.2 \mathrm{~mm}$ \\
\hline $1 / 6400$ & $(+)$ & $0.1-0.3 \mathrm{~mm}$ \\
\hline $1 / 12800$ & + & $0.1-0.3 \mathrm{~mm}$ \\
\hline $1 / 25600$ & ++ & $0.2-0.4 \mathrm{~mm}$ \\
\hline $1 / 51200$ & ++ & $0.2-0.4 \mathrm{~mm}$ \\
\hline $1 / 102400$ & ++ & confluent \\
\hline $1 / 204800$ & $++(+)$ & confluent \\
\hline $1 / 409600$ & +++ & $0.2-0.4 \mathrm{~mm}$ \\
\hline $1 / 819200$ & +++ & $0.1-0.2 \mathrm{~mm}$ \\
\hline $1 / 1638400$ & $++(+)$ & \\
\hline $1 / 3246800$ & + & IgM \\
\hline
\end{tabular}

${ }^{3}$ antiserum used was rabbit anti-mouse $\operatorname{IgG}, \operatorname{IgA}, \operatorname{IgM}$ $(\mathrm{H}+\mathrm{L})$.

b Nfld.M2 hybridoma cells were used at a concentration of $5 \times 10^{3}$ cells per chamber of a slide.

$+++\quad$ approx. 95-100\% target cell lysis

$+++(+) \quad$ approx. $85-90 \%$ target cell lysis

$+++\quad$ approx. $75-80 \%$ target cell lysis

$++(+) \quad$ approx. $60-70 \%$ target cell lysis

$++\quad$ approx. 50-55\% target cell lysis

$+(+) \quad$ approx. $35-45 \%$ target cell lysis

$+\quad$ approx. $20-30 \%$ target cell lysis

(+) approx. $10-15 \%$ target cell lysis less than $10 \%$ target cell lysis

${ }^{c}$ some plaque sizes are not given because either there were no plaques present or they were confluent. 
decline or loss of antibody production by hybridoma cells with time has been reported before (Eshhar, Z., 1985). It was felt that recloning Nfld.M2 hybrids might increase the number of $\mathrm{PFC}$ and hence increase the number of plaques. The hybrids were therefore cloned out at as described in materials and methods, section 2.11. After recloning, 14 out of the 60 wells plated at 1 and 0.5 cell/well achieved $50 \%$ confluency and the supernatants from these wells were tested on CDC. Out of these 14 wells, 13 were positive and one was negative for specific antibody production. Three of the wells that were very strongly positive were grown up separately for testing in the plaque assay. For clone 1, the plaque assay (slide method \#2) was performed twice a week for the first month and then once every one or two weeks for another month. For clones 2 and 3 , the plaque assay was done less often. The slides were set up with target cells (C.H.M.), hybridoma cells ranging from $6.2 \times 10^{2}$ to $1 \times 10^{4}$ per chamber and PI. Complement was added after incubation.

The results for clones 1, 2 and 3 are summarized in figures 11a, b, and c, respectively. The graphs show the average number of plaques per 5000 hybridoma cells versus the number of days. Day 0 represents the day Nfld.M2 clones were first set up on the plaque assay, two weeks after cloning. On that day, the earlier (not recloned) culture of Nfld.M2 hybrids was also set up in parallel with the cloned cells and the average plaques/5000 cells was determined to be 72 for the earlier culture. From the graphs, it can be seen that at no time were there greater than 1111 PFC found per 5000 hybridoma cells 
Figures 11a, b, c: Change with time after cloning in percent of hybridoma cells secreting antibody (slide method \#2).

Three separate graphs, for three clones of Nfld.M2 hybridoma cells, were plotted to show the average plaques produced per 5000 hybridoma cells versus days. 


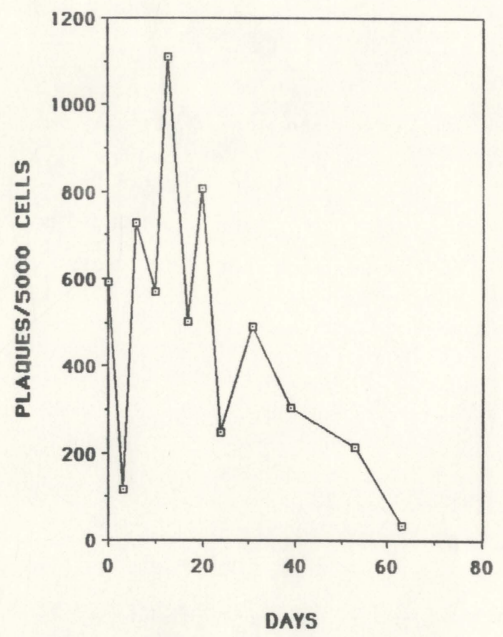

Figure 11a: Clone 1 


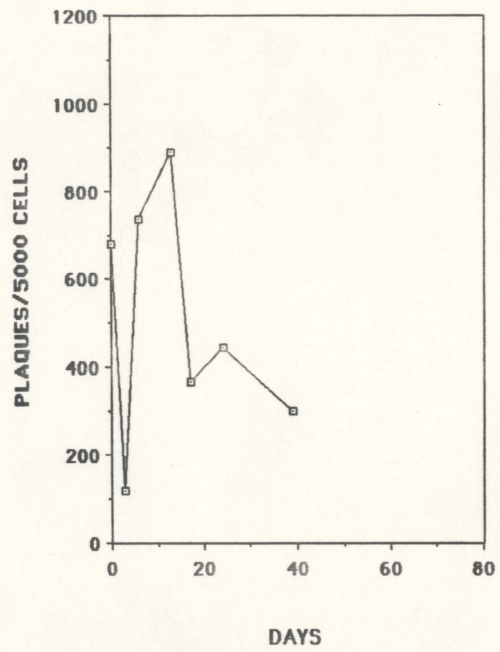

Figure 11b: Clone 2 


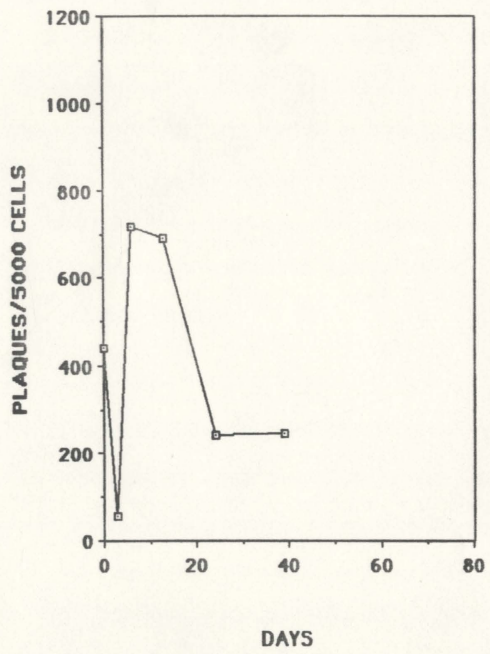

Figure 11c: Clone 3 
plated; there was a remarkable variability in the number of PFC for all three clones each time they were set up; a sharp drop in the number of PFC was observed for each clone at day 3 ; there was a peak response $(22 \%)$ at approximately two weeks and then gradually a drop in the number of PFC $(0.5 \%)$ with time. Since each clone came from 0.5-1 cell/well and cell growth was obtained in only 14 out of the 60 wells, it is fair to conclude that at least one of these was a clone. As they behaved similarly, probably all three were clones. It is clear that antibody secretion, at a level detectable by this assay, occurs only in a small minority of cells in a clone, at any one time. This interesting and unexpected finding is dealt with in more detail in the 'discussion' section.

\subsubsection{Experiments with hybridoma cells from Nfld.M1 cultures}

Nfld.M1 is a non-cytotoxic antibody of IgG1 subclass with anti-DR4 specificity (materials and methods, section 2.3.1A). It had previously been clone twice. The following experiments were set up to see if Nfld.M1 antibody could be used in a complement dependent lysis method by the addition of an anti-Ig antiserum (rabbit anti-mouse IgG, IgA and IgM). T.P. cell line cells (DR2,4, see table 1) were used as a source of target cells. These experiments were set up twice using both slide methods \#1 and \#2. In method \#1, the slides were set up with Nfld.M1 hybridoma cells at a concentration of $1 \times 10^{6}$ per chamber, together with target cells, serial dilutions of antiserum ranging 
from $1 / 2$ to $1 / 8192$, PI and complement. In method \#2, slides were set up with target cells, Nfld.M1 hybridoma cells at a concentration of $1 \times 10^{6}$ per chamber and PI. After incubation, serial dilutions of antiserum ranging from $1 / 2$ to approximately $1 / 1 \times 10^{6}$ were added to the slides. Complement was added after another incubation. No effect of antiserum was observed in either method and these slides were found to be no different from the ones that contained hybridoma cells but no antiserum. Approximately $20 \%$ cell lysis was seen in all these slides whereas in the slides without hybridoma cells, only $5 \%$ lysis was seen. Thus, contrary to expectation, Nfld.M1 could not be used in this plaque assay even with the addition of a second developing antibody.

\subsubsection{Experiments with supernatant from Nfld.H1 cultures on vari- ous target cells}

All the experiments described above involved the use of mouse hybridoma cells. The following experiments were done using human hybridoma cells, referred to as Nfld.H1 (materials and methods, section 2.3.1B) in order to see if this plaque assay could be used in a human hybridoma system. Nfld.H1 antibody is an IgM and is known to be cytotoxic in CDC, when used undiluted, although it has variable reactivity depending on the target cell line used. It is known to be most positive on DR2 and DQw1 positive cell lines. In two separate experiments, slides were set up with undiluted supernatant from an overgrown culture of Nfld.H1 which had been cloned twice, along with various 
target cells of different HLA phenotypes (table 1) and PI. Complement was added after incubation. No lysis was seen at all for any of the target cells. The supernatant was then concentrated 50 -fold and set up again. The results are shown in table 7. E.A., K.H. and B.C. were negative with Nfld.H1 and the rest of the cell lines reacted with it to varying degrees. The reactions did not correlate well with the DR and DQ specificity of the cells.

Experiments with Nfld.H1 hybridoma cells were also done to see if plaques could be produced. In two separate experiments, target cells (C.H.M.), hybridoma cells at a concentration of $1 \times 10^{6}$ per chamber and PI were set up on slides and incubated. Complement was then added and the slides were dried and examined. The negative control gave $5 \%$ lysis. The slides with hybridoma cells gave approximately $15-20 \%$ lysis but no definite plaques. Experiments with lower concentrations of hybridoma cells also did not produce any plaques.

\subsubsection{Experiments with EBV-transformed cells as ASC}

B cells from a male volunteer (W.H.M.) who had been immunized with peripheral blood lymphocytes (PBLs) from another male volunteer (C.H.M.) were isolated at various intervals after immunization and transformed with EBV (materials and methods, section 2.3.1B). These EBV-transformed cells were used in the plaque assay as a source of ASC. The ultimate aim of this experiment was to determine the frequency of specific antibody-forming cells in 


\section{Table 7}
Degree of lysis of various target cells when tested with concentrated (50-fold) Nfld.H1 antibody (slide method \#2)

\begin{tabular}{|c|c|c|c|}
\hline Target Cell Line & DR & DQ & Degree of Lysis* \\
\hline E.A. & 2,3 & w1 & - \\
B.C. & 4,5 & w3,w3 & - \\
D.C. & $2, ? w 6$ & w1 & $++(+)$ \\
E.C. & 2 & w1, & +++ \\
M.C. & 2,3 & w1,w3 & ++ \\
K.H. & 3,4 & w2,w3 & - \\
C.A.K. & 2,5 & w1,w3 & ++ \\
C.H.M. & 1,3 & w1,w2 & ++ \\
L.R. & $2, w 9$ & w1 & + \\
GM3161 & 2,2 & w1 & ++ \\
\hline
\end{tabular}

*++++ approx. 95-100\% target cell lysis

$+++(+) \quad$ approx. $85-90 \%$ target cell lysis

$+++\quad$ approx. $75-80 \%$ target cell lysis

$++(+) \quad$ approx. $60-70 \%$ target cell lysis

$++\quad$ approx. $50-55 \%$ target cell lysis

$+(+) \quad$ approx. $35-45 \%$ target cell lysis

$+\quad$ approx. 20-30\% target cell lysis

(+) $\quad$ approx. $10-15 \%$ target cell lysis

less than $10 \%$ target cell lysis 
the blood and to determine the time of the peak response. An immediate objective was to see if this plaque assay could be used for this type of human ASC. These are results from four separate time points (i)-(iv) and they are summarized in table 8 .

(i) Cells from four culture tubes containing cells isolated 11 days postimmunization were set up on the plaque assay. These cells had been in culture for 8 days and a differential count revealed approximately $3 \times 10^{5}$ cells/tube of which approximately $10-20 \%$ were blasts. One slide was set up per tube along with target cells (C.H.M.) and PI. Complement was added after incubation. Out of these four slides, three did not contain any plaques and one contained 15 plaques. These plaques were quite clear and distinct and ranged in size from 0.1 to $0.2 \mathrm{~mm}$.

(ii) Cells from one culture tube containing $\mathrm{B}$ cells isolated 14 days postimmunization were set up on the plaque assay. They had been in culture for 5 days and a differential count revealed approximately $3 \times 10^{5}$ cells/tube of which approximately $5 \%$ were blasts. No plaques were found.

(iii) Cells from four culture tubes containing B cells isolated 19 days postimmunization were set up on the plaque assay. They were set up 9 (1 tube), 11 (1 tube), and 14 ( 1 tube with EBV and one without EBV) days after culturing. None, 2, 8, 1 plaques were found, respectively. The plaques ranged from 0.1-0.2 $\mathrm{mm}$ in size. 
Table 8

Number of plaques formed with human PBLs collected and transformed with EBV at various days post-immunization

\begin{tabular}{|c|c|c|c|}
\hline \multirow{2}{*}{ Tube \# } & \multicolumn{2}{|c|}{ Days } & \multirow{2}{*}{ Number of Plaques } \\
\cline { 2 - 3 } & Post-Immunization & \\
& & In Culture & \\
\hline 1 & 11 & 8 & 0 \\
2 & 11 & 8 & 0 \\
3 & 11 & 8 & 0 \\
4 & 11 & 8 & 15 \\
\hline 5 & 14 & 9 & 0 \\
\hline 6 & 19 & 11 & 0 \\
7 & 19 & 14 & 2 \\
8 & 19 & 8 & 8 \\
9 & 19 & 11 & 1 \\
\hline 10 & 22 & (no EBV) & 0 \\
11 & 22 & & 0 \\
\hline
\end{tabular}

${ }^{3}$ represents days from immunization to blood collected.

${ }^{b}$ plaques ranged from 0.1-0.2 $\mathrm{mm}$ in diameter. 
(iv) Cells from two culture tubes containing $\mathrm{B}$ cells isolated 22 days post-immunization were set up on the plaque assay. They had been in culture 8 and 11 days. No plaques were found.

In conclusion, EBV-transformed cells can be used in the plaque assay as a source of ASC. The plaques formed are clear and distinct although smaller than the ones found for mouse hybridoma cells. This may probably be due to lower antibody secretion by the EBV-transformed cells as compared to the mouse hybridoma cells. From the above experiments, it is not possible to establish the time of the peak response. 


\section{CHAPTER 4}

\section{DISCUSSION}

\subsection{Specificity of the plaque assay}

The specificity of the plaque assay was clearly demonstrated by the fact that when various target cells of different phenotypes were incubated with Nfld.M2 antibody which is anti-HLA-A2 and A28, lysis was observed only in the cells that expressed A2 and/or A28. No lysis was seen when cells expressing an unrelated antigen were used as targets (results, section 3.3.6). The fact that Nfld.M2 antibody which is of IgG2a subclass causes lysis of nucleated target cells shows that the density of the epitopes, in this case on HLA class 1 molecules, is high enough on the target cell membrane for the IgG molecules which bind to them to activate the complement system. This contrasts with the antigens present on the surface of sheep erythrocytes since they are often unable to combine with IgG in a way that triggers the complement cascade. The latter antibodies usually need to be revealed by the addition of anti-IgG antibody to the preparation (Sterzl and Riha, 1965; Dresser and Wortis, 1965).

The plaques obtained were usually clear and distinct with diameters ranging from 0.1-0.4 mm. Fuji, Zaleski and Milgrom (1971), using thymus cells as targets reported plaque diameters of 0.1-0.8 mm. Taylor and Bennett (1973), using tumor (lymphoma) cells as targets, obtained plaque diameters ranging 
from 0.1-0.2 mm. When RBC were used as targets, plaque diameters ranging from 0.1-1.0 mm were obtained (Jerne, Henry, Nordin, Fuji, Koros and Lefkovits, 1974).

The variation in plaque size, when a hybridoma producing a monoclonal antibody is used, could be due to the rate of antibody secretion by the plaqueforming cell (PFC) and the rate of diffusion of these molecules from the PFC to the target cells (Bussard, 1980). Other factors that affect plaque size in a more heterogeneous population of ASC is epitope density, and the affinity and avidity of the antibody secreted (Jerne, Henry, Nordin, Fuji, Koros and Lefkovits, 1974, Bussard, 1980).

Variation in plaque size can also be due to the type of cells used as targets and their susceptibility to complement-mediated lysis. RBC are found to be more susceptible to lysis by complement because the formation of a single complement channel per cell is sufficient to cause lysis, whereas, with nucleated cells, several complement channels are required for lysis (Koski, Ramm, Hammer, Mayer and Shin, 1983). This is because the rate of channel elimination by the nucleated cells is high, whereas, for erythrocytes, it is nil. Also, nucleated cells have effective membrane-associated ion pumps which counteract the disturbance of osmotic balance that occurs when there is an ion flux through the complement channels. Lastly, the osmotic fragility of nucleated cells is lower than that of RBC (Ramm, Whitlow and Mayer, 1984). 


\subsection{Comparison of slide method \#1 with method \#2}

Slide method \#2 was found to be more sensitive than slide method \#1 in detecting plaques. When the two methods were set up in parallel and incubated for the same length of time, the ratio of PFC for slide method \#1 as compared to slide method \#2 was approximately 1:7 (results, section 3.4.3). This difference may be due to the fact that in slide method \#2, complement was present in excess whereas in slide method \#1, a limited volume of complement was added. Also, since for slide method \#1, complement is present right from the start it may perhaps be uselessly consumed. Alternatively, the rabbit serum which is used as a complement source may act as an inhibitor of successful antibody secretion in some way. This theory can be tested by setting up method \#2 with complement present both from the beginning and added later.

\subsection{Percentage of Nfld.M2 hybridoma cells forming plaques}

In slide method \#1, less than $5 \%$ of Nfld.M2 hybridoma cells that were plated were found to be forming plaques (results, section 3.3.9). This percentage of PFC was increased (22\%) in slide method \#2 since it was found to be more sensitive than slide method \#1, and also the Nfld.M2 hybridoma cells had been recently cloned. The finding that only a small proportion of hybridoma cells, in a cloned culture, were actually secreting complement fixing anti- 
body, at any one time, was unexpected. The possibility that the experimental manipulations, especially exposing the hybrids to $45^{\circ} \mathrm{C}$, might be altering the viability and/or function of the hybrids was considered but later ruled out when repeated trials, with variations in the temperature and the time of exposure to the raised temperature, showed no consistent effect (results, section 3.3.9A \& B). Following is a review of some of the results obtained by other investigators using various hybridomas and myelomas to produce specific plaques.

Bussard (1980) used a hybridoma resulting from a fusion between immune spleen cells and a myeloma. It produced an anti-SRBC antibody of IgM class. He found that the number of cells that formed plaques in a direct hemolytic plaque assay depended on the 'period of growth at which they were collected'. If the hybridoma cells were taken at the beginning of the exponential growth, $10-15 \%$ formed plaques whereas if they were taken the end of the exponential growth, $65-70 \%$ formed plaques. He concluded that this must reflect the operation of a regulatory mechanism in vitro.

Rector, Lang, Carter, Kelly, Bundesen, Böttcher and Sehon (1980) used hybridomas resulting from the fusion between immune spleen cells and P3X20 myeloma cells. They obtained approximately $30 \%$ PFC with both IgE and IgG1-secreting hybridomas using the reverse hemolytic plaque assay (RHPA; introduction, section 1.3); and $31 \%$ PFC using a hybridoma secreting an antiSRBC antibody of IgM class in a direct hemolytic plaque assay. They agreed 
with the findings of Bussard (1980) and concluded that the majority of the cells maintained in non-synchronized cultures were in a non-secreting phase of their cycle when tested.

Möller and Borrebaeck (1985), used a hybridoma (1D5-8B) that resulted from a fusion between immune spleen cells and SP2/O-Ag14 plasmacytoma. It was cloned three times before it was used in the filter immuno-plaque assay (FIPA; introduction, section 1.4). In their assay, approximately $5 \%$ of the cells were found to be producing plaques.

When myeloma cells were used as a source of antibody-secreting cells (ASC), $\quad 10-70 \%$ (Gronowicz, Coutinho and Melchers, 1976; RHPA), 10-15\% (Rector, Carter, Kelly, Lang and Sehon, 1979; RHPA), and 32-39\% (Holt, Cameron, Stewart, Sedgwick and Turner, 1984; ELISA-plaque assay; introduction, section 1.4) were found to be producing plaques. It was concluded that the non-plaque-forming fraction of the cells could be either precursors not yet capable of secreting or end cells that had lost the capacity to secrete, or else cells in the non-secreting phase of their cell cycle.

From the evidence so far, the low percentage of PFC observed in hybridoma cell cultures is attributed to the fact that, in non-synchronized cultures, the majority of the cells are in a non-secreting phase of their cell cycle. Whether this is the case with Nfld.M2 hybridoma cells can be tested by synchronizing the cell cultures and then testing the cells in a plaque assay over a 
period of time. Some of the findings in this lab, using human hybridoma cells as a source of ASC in a RHPA, have suggested that nutrition may be involved in reducing the number of PFC. There may be a deficiency of growth factors, for example, B cell differentiation factor, which is known to induce antibody production by B cells, (Muraguchi, Kehrl, Butler and Fauci, 1984), or of some essential nutrients, such as a particular amino acid that may be required by the cells for antibody production. Carefully controlled experiments, in terms of culture conditions, nutrients and growth factors are required to determine the effect of these on the number of PFC.

\subsection{Effect of anti-immunoglobulin antiserum}

The prozone effect observed for slide method \#1 was thought to occur because the antiserum was present right from the time when the slides were first set up (results, section 3.3.10). It was thought that the anti-Ig formed complexes with the secreted antibody and thus affected its ability to diffuse through the agar and bind to the target cells. For this reason, slide method \#2 was developed in which the surface of the agar was exposed so that the antiserum could be added after the initial incubation with the ASC. The same prozone effect was observed again, although the optimal concentration of antiserum required to increase target cell lysis was considerably lower (1/4001/800 for slide method \#1; 1/409,600-1/819,200 for slide method \#2). The fact that the antiserum needed to be diluted more for slide method \#2 in 
order to see the enhancing effect could be due to differences in the volume of antiserum added, since only $5 \mu \mathrm{l}$ of antiserum was added to the slides in slide method \#1, whereas, in slide method \#2, the slides were flooded with antiserum. The fact that the same prozone effect was also observed for slide method \#2 invalidates the argument presented for slide method \#1 that it was due to the antiserum being present right from the beginning.

The inhibition in plaque formation observed for both methods at high concentrations of antiserum was similar to that observed by Šterzl and ̌̌iha (1965) and Dresser and Wortis (1965). They found that an optimal concentration of antiserum was required for maximal development of plaques and that higher concentrations resulted in inhibition. Gronowicz, Coutinho and Melchers (1976), using the RHPA, also reported that plaque formation was highly dependent on the concentration of developing antibody. They showed that too low or too high a concentration of antiserum resulted in inhibition of plaque formation.

The increase in target cell lysis (plaque diameter) due to a secondary antibody at high hybridoma cell concentrations, which was found for both methods, is puzzling. One possible explanation could be that as the hybridoma cells secrete their antibody, it diffuses through and coats peripheral target cells with sublytic doses of antibody. Since the concentration of hybridoma cells is high, and consequently the distance between two PFC is low, there may be a certain amount of overlapping, i.e. peripheral target cells may 
be being coated with antibody from more than one PFC. Such a sublytic dose may not be enough to activate the complement or alternatively, it is known that even if the complement system is activated, it may not be enough to cause lysis, since lysis of nucleated mammalian cells by complement requires formation of several channels per cell (Koski, Ramm, Hammer, Mayer, and Shin, 1983). The addition of antiserum may result in enough $\mathrm{Fc}$ regions being exposed, that complement activation results in target cell lysis, which may result in bigger plaques (confluent plaques).

At low hybridoma cell concentrations, the increase in target cell lysis by the addition of optimal dilutions of antiserum is not seen. This may be due to the fact that the distance between two PFC is large and thus there is no overlapping, i.e. the peripheral target cells are just coated with sublytic doses of antibody from one PFC and this may not be enough to react with antiserum and cause target cell lysis. This interpretation suggests the possibility of using a second antibody in the agar at sublytic concentrations, to increase the sensitivity of the plaque method, at least in terms of plaque size, if not of plaque number.

\subsection{Cloning}

Nfld.M2 hybridoma cells were cloned and the number of PFC was followed over a period of time (results, section 3.5.1). The number of PFC after cloning increased from 72 per 5000 cells plated for the earlier (not recloned) 
cells to 594, 680 and 441 for clones 1, 2, and 3, respectively. There was a sharp peak response for all three clones at approximately 2 weeks of testing. The maximum number of PFC observed was for clone 1 at two weeks (1111 out of 5000 cells plated; results, figure 11a). After the peak, there was a gradual decline in antibody production till after two months, approximately $0.5 \%$ of the cells were making plaques.

This drop in PFC cannot by explained by mutation, or loss of chromosomes, since such changes are irreversible and this does not seem to be the case with these hybridoma cells for the following reasons. First, it was found that when these cells were cloned out at $0.5-1$ cell/well, more than $90 \%$ of the wells tested were positive for specific antibody. Second, the number of cells secreting antibody varied from day to day. Again, as in section 4.3, this low number of PFC (22\%), which dropped to an even lower number $(0.5 \%)$ may be due to lack of nutrition, perhaps some factor that is limiting in the cell culture. Alternatively, the majority of the cells may be in a non-secreting phase of their cell cycle, or both. The first hypothesis can be tested by adding growth factors, known amounts of different amino acids and other nutrients to the cell cultures to see if these have an effect on the number of PFC. The second hypothesis can be tested, as mentioned before, by synchronizing the cell culture and then testing the hybridoma cells in a plaque assay over a period of time. 


\subsection{Nfld.M1}

Nfld.M1 produces a non-complement fixing antibody of IgG1 subclass and anti-DR4 specificity. Efforts to induce target cell lysis or plaque formation with Nfld.M1 by the addition of antiserum were unsuccessful, for both slide methods \#1 and \#2 (results, section 3.5.2). Plaques observed by other investigators, using nucleated cells as targets, have been IgM plaques. Nordin, Cerottini and Brunner (1971) were unable to demonstrate IgG plaques by the use of specific antisera to each of the IgG subclasses. The reason why the addition of antiserum does not induce the activation of complement when nucleated cells are used as targets as it does when erythrocytes are used, is puzzling. Perhaps, the Ig-anti Ig complex formed on the surface of the nucleated cells gets capped and internalized. This is common with nucleated cells but not with erythrocytes. Alternatively, the Ig-anti-Ig complex may be activating the complement, but this may not be sufficient to cause target cell lysis. If the epitope density on HLA class II molecules is low, then even with the addition of antiserum, not enough complement channels may be forming to cause lysis of the target cells as it would with erythrocytes.

The latter hypothesis can be tested by treating the target cells with puromycin. Puromycin inhibits protein synthesis and it has been shown to increase the osmotic fragility of nucleated cells; to reduce the rate of ion pumping; to reduce the rate of membrane repair by affecting the synthetic capability of the cell; and to reduce the rate of channel elimination (Ramm, Whitlow and 
Mayer, 1984). All these factors combine to make the cells more susceptible to lysis. Therefore, the target cells can first be treated with puromycin and then set up on a plaque assay with Nfld.M1 to see if plaques can be observed by the addition of antiserum.

\subsection{Nfld.H1}

Nfld.H1 is an IgM producing human-human hybridoma. It was of interest to see if plaques could be produced with these hybrids since the secreted antibody has been shown to be cytotoxic. Neither plaques nor target cell lysis was observed when Nfld.H1 hybridoma cells were set up on the plaque assay. This was perhaps not surprising since the supernatant from an overgrown culture of Nfld.H1 had to be concentrated 50 -fold before any target cell lysis was observed. Human hybridomas are known to secrete low amounts of antibody as compared to mouse hybridomas. Incubation of the slides for up to 6 hours ( 2 hour incubations are normally performed) with the hybridoma cells did not have any effect (data not given). Incubations longer than 6 hours resulted in non-specific target cell death as well as fading of the fluorescence. Therefore, whether longer incubations result in enough antibody production to cause target cell lysis could not be determined. Nordin, Cerottini and Brunner (1971), using spleen cells from immunized mice and nucleated target cells found plaques after $\mathbf{2 4}$ hours incubation. Such long incubations could not be performed for this method as the fluorescence tended to fade and leak out of the 
target cells 10-12 hours after labelling.

\subsection{EBV-transformed cells}

Plaques were obtained when EBV-transformed human cells were used as ASC. The plaques were smaller than the ones obtained with mouse hybridoma cells, probably due to lower antibody secretion, but they were clear and distinct. The successful adaptation of this plaque method for use with human cells should be valuable to people attempting to produce human monoclonal antibodies since it will illuminate events in a cell culture at the most revealing level, that of the single cell. 


\section{REFERENCES}

1. Bagasara, O. \& Damjanov, I. (1982). Detection of plaque-forming cells by a latex bead method. Journal of Immunological Methods 49, 283-292.

2. Beaudoin, R., Valet, J.-P. \& Hébert, J. (1980). Detection of immunoglobulin-secreting lymphocytes by the use of a hemolytic plaque assay in liquid phase. Journal of Immunological Methods 35, 91-95.

3. Bird, A.G. \& Britton, S. (1979). A new approach to the study of human $\mathrm{B}$ lymphocyte function using an indirect plaque assay and a direct $\mathrm{B}$ cell activator. Immunological Reviews 45, 41-67.

4. Bodmer, W., Tripp, M. \& Bodmer, J. (1967). Application of fluorochromatic cytotoxicity assay to human leukocyte typing. In Histocompatibility Testing, ed. CURTONI, E.S., MATTIUZ, P.L. \& TOSI, R.M., pp. 341-350, Williams and Wilkins Co., Baltimore.

5. Böyum, A. (1968). Isolation of mononuclear cells and granulocytes from human blood. Scandinavian Journal of Clinical and Laboratory Investigation 21(Suppl. 97), 77-89.

6. Bruning, J.W., Claas, F.H.J., Kardol, M.J., Lansbergen, Q., Naipal, A.M. \& Tanke, H.J. (1982). Automated reading of HLA-A,B,C typing and screening. The propidium iodide (PI) method. Human Immunology $\mathbf{5}$, 225-231.

7. Bussard, A.E. (1980). Plaque morphology studied with immune hybridomas. Molecular Immunology 17, 57-63.

8. Coons, A.H., Creech, H.J., Jones, R.N. \& Berliner, E. (1942). The demonstration of pneumococcal antigen in tissues by the use of fluorescent antibody. Journal of Immunology 45, 159-170.

9. Coons, A.H., Leduc, E.H. \& Connolly, J.M. (1955). Studies on antibody production: 1. A method for the histochemical demonstration of specific antibody and its application to a study of the hyperimmune rabbit. Journal of Experimental Medicine 102, 49-60.

10. Cunningham, A.J. (1965). A method of increased sensitivity for detecting single antibody-forming cells. Nature 207, 1106-1107. 
11. Cunningham, A.J., Smith, J.B. \& Mercer, E.H. (1966). Antibody formation by single cells from lymph nodes and efferent lymph of sheep. Journal of Experimental Medicine 124, 701-714.

12. Cunningham, A.J. \& Szenberg, A. (1968). Further improvements in the plaque technique for detecting single antibody-forming cells. Immunology 14, 599-600.

13. Czerkinsky, C.C., Nilsson, L.-§., Nygren, H., Ouchterlony, Ö. \& Tarkowski, A. (1983). A solid-phase enzyme-linked immunospot (ELISPOT) assay for enumeration of specific antibody-secreting cells. Journal of Immunological Methods 65, 109-121.

14. Czerkinsky, C.C., Tarkowski, A., Nilsson, L.-A., Ouchterlony, O., Nygren, H. \& Gretzer, C. (1984). Reverse enzyme-linked immunospot assay (RELISPOT) for the detection of cells secreting immunoreactive substances. Journal of Immunological Methods 72, 489-496.

15. Dresser, D.W. \& Wortis, H.H. (1965). Use of an antiglobulin serum to detect cells producing antibody of low hemolytic efficiency. Nature 208, 859-861.

16. Drover, S., Codner, D., Fuad, N., Marshall, W.H., Mervart, H., Wasi, Y. \& Yun, J. Production of a human monoclonal antibody against an HLA polymorphism expressed only on B cell lines, in preparation.

17. Drover, S., Marshall, W.H. \& Mervart, H. A mouse monoclonal antibody against HLA-A2 and HLA-A28, in preparation.

18. Drover, S., Marshall, W.H. \& Younghusband, H.B. (1985). A mouse monoclonal antibody with HLA-DR4 associated specificity. Tissue Antigens 26, 340-343.

19. Eby, W.C., Chong, C.A., Dray, S. \& Molinaro, G.A. (1975). Enumerating immunoglobulin-secreting cells among peripheral human lymphocytes. A hemolytic plaque assay for a B cell function. Journal of Immunology 115, 1700-1703.

20. Eshhar, Z. (1985). Monoclonal antibody strategy and techniques. In Hybridoma Technology in the Biosciences and Medicine, ed. SPRINGER, T.A., pp. 3-41, Plenum Press, New York, London. 
21. Fagraeus, A. (1948). The plasma cellular reaction and its relation to formation of antibodies in vitro. Journal of Immunology 58, 1-13.

22. Fuji, H., Zaleski, M. \& Milgrom, F. (1971). Allogeneic nucleated cells as immunogen and target for plaque-forming cells in mice. Transplantation Proceedings 3, 852-855.

23. Ginsburg, W.W., Finkelman, F.D. \& Lipsky, P.E. (1978). Circulating and mitogen-induced immunoglobulin-secreting cells in human peripheral blood: Evaluation by a modified reverse hemolytic plaque assay. Journal of Immunology 120, 33-39.

24. Gronowicz, E., Coutinho, A. \& Melchers, F. (1976). A plaque assay for all cells secreting Ig of a given type or class. European Journal of Immunology 6, 588-590.

25. Holt, P.G., Cameron, K.J., Stewart, G.A., Sedgwick, J.D. \& Turner, K.J. (1984). Enumeration of human immunoglobulin-secreting cells by the ELISA-plaque method: IgE and IgG isotypes. Clinical Immunology and Immunopathology, 30, 159-164.

26. Ingraham, J.S. \& Bussard, A. (1964). Application of a localized hemolysin reaction for specific detection of individual antibody-forming cells. Journal of Experimental Medicine 119, 667-684.

27. Jerne, N.K., Henry, C. Nordin, A.A., Fuji, H., Koros, A.M.C. \& Lefkovits, I. (1974). Plaque forming cells: Methodology and theory. Transplantation Reviews 18, 130-191.

28. Jerne, N.K. \& Nordin, A.A. (1963). Plaque formation in agar by single antibody-producing cells. Science 140, 405.

29. Kappler, J.W. (1974). A micro-technique for hemolytic plaque assays. Journal of Immunology 112, 1271-1274.

30. Katz, D.H., Faulkner, M., Katz, L.R., Lindh, E., Leonhardt, C.C., Herr, K. \& Tung, A.S. (1977). A rapid semi-automated counting procedure for enumeration of antibody-forming cells in gel and nucleated cells in suspension. Journal of Immunological Methods 17, 285-291. 
31. Kennedy, J.C. \& Axelrad, M.A. (1971). An improved assay for hemolytic plaque-forming cells. Immunology 20, 253-257.

32. Kissinger, R. \& Myl, A.D. (1984). Improvements to the plaque assay for antibody secreting cells. Journal of Immunological Methods 66, 377-382.

33. Koski, C.L., Ramm, L.E., Hammer, C.H., Mayer, M.M. and Shin, M.L. (1983). Cytolysis of nucleated cells by complement: cell death displays multi-hit characteristics. Proceedings of the National Academy of Sciences of the United States of America 80, 3816-3820.

34. Kozbor, D., Lagarde, A.E. \& Roder, J.C. (1982). Human hybridomas constructed with antigen-specific Epstein-Barr virus-transformed cell lines. Proceedings of the National Academy of Sciences of the United States of America 79, 6651-6655.

35. Lake, P. (1976). Antibody response induced in vitro to the cell-surface alloantigen Thy-1. Nature 262, 297-298.

36. Leduc, E.H., Coons, A.H. \& Connolly, J.M. (1955). Studies on antibody production: II. The primary and secondary responses in the popliteal lymph node of the rabbit. Journal of Experimental Medicine 102, 61-72.

37. Lefkovits, I. (1972). Induction of antibody-forming cell clones in microcultures. European Journal of Immunology 2, 360-366.

38. Lefkovits, I. \& Kamber, O. (1972). A replicator for handling and sampling microcultures in tissue culture trays. European Journal of Immunology 2, 365-366.

39. Librach, C.L. \& Mackay, I.R. (1982). Rapid replicate reverse hemolytic plaque assay directly in microwells used for tissue culture. Journal of Immunological Methods 52, 43-49.

40. Mäkelä, O. \& Nossal, G.J.V. (1961). Bacterial adherence: A method for detecting antibody production by single cells. Journal of Immunology 87, 447-456.

41. Miller, G. \& Lipman, M. (1973). Release of infectious Epstein-Barr virus by transformed marmoset leukocytes. Proceedings of the National Academy of Sciences of the United States of America 70, 190-194. 
42. Mishell, R.I. \& Dutton, R.W. (1967). Immunization of dissociated spleen cell cultures from normal mice. Journal of Experimental Medicine 126, 423-442.

43. Mizoguchi, K., Nakashima, I., Isobe, K.-I., Saito, M., Nagase, F., Kato, N. \& Shimokata, K. (1984). Paradoxical effects of LPS on the T-cellindependant type 2 anti-H-2 alloantigen antibody responses to allogeneic erythrocytes. Transplantation 37, 101-105.

44. Molinaro, G.A. \& Dray, S. (1974). Antibody coated erythrocytes as a manifold probe for antigens. Nature 248, 515-517.

45. Möller, S.A. \& Borrebaeck, C.A.K. (1985). A filter immuno-plaque assay for the detection of antibody-secreting cells in vitro. Journal of Immunological Methods 79, 195-204.

46. Moore, J. \& Calkins, C. (1983). Formation of antigen-specific foci as a complement independent assay for individual antibody-secreting cells. Journal of Immunological Methods 63, 377-384.

47. Muraguchi, A., Kehrl, J.H., Butler, J.L. \& Fauci, A.S. (1984). Regulation of human B-cell activation, proliferation and differentiation by soluble factors. Journal of Clinical Immunology 4, 337-347.

48. Nakashima, I., Clark, E.A., Lake, P., Kato, N., Nagase, F., Mizoguchi, K., Isobe, K.-I. \& Saito, M. (1983). Evidence for the erythrocyte as the principal antigenic cell type that triggers primary $\operatorname{IgM}$ antibody responses to H-2D alloantigens. Transplantation 35, 180-184.

49. Nakashima, I. \& Lake, P. (1979). A novel subset of antigenic cells triggers B-cell responses to MHC antigens. Nature 279, 716-718.

50. Nakashima, I., Mizoguchi, K., Kato, N., Nagase, F., Isobe, K.-I., Saito, M. \& Suzuki, K. (1982). Control of primary IgM antibody responses to $\mathrm{H}-2$ alloantigens by antigen-bearing live B lymphocytes. European Journal of Immunology 12, 713-719.

51. Nordin, A.A., Cerottini, J.C. \& Brunner, K.T. (1971). The antibody response of mice to allografts as determined by a plaque assay with allogeneic target cells. European Journal of Immunology 1, 55-56. 
52. Nossal, G.J.V. (1959b). Antibody production by single cells: II. The difference between primary and secondary response. British Journal of Experimental Pathology 40, 118-124.

53. Nossal, G.J.V. (1959). Antibody production by single cells: III. The histology of antibody production. British Journal of Experimental Pathology 40, 301-311.

54. Nossal, G.J.V. \& Lederberg, J. (1958). Antibody production by single cells. Nature 181, 1419-1420.

55. Nossal, G.J.V., Bussard, A.E., Lewis, H. \& Mazie, J.C. (1970). In vitro stimulation of antibody formation by peritoneal cells. 1. Plaque technique of high sensitivity enabling access to the cells. Journal of Experimental Medicine 131, 894-916.

56. Nossal, G.J.V., Szenberg, A., Ada, G.L. \& Austin, C.M. (1964). Single cell studies on $19 \mathrm{~S}$ antibody production. Journal of Experimental Medicine 119, 485-502.

57. Oi, V.T. \& Herzenberg, L.A. (1980). Immunoglobulin producing hybrid cell lines. In Selected Methods in Cellular Immunology, eds. MISHELL, B.B. \& SHIGI, S.M., pp. 351-372, W.H. Freeman \& Co., San Francisco.

58. Pang, G.T.M., Gatman, M.R., Drummond, J.M. \& Booth, R.J. (1981). A sensitive micromethod for measuring human reverse hemolytic plaqueforming cells. Journal of Immunological Methods. 40, 253-258.

59. Pick, E. \& Feldman, J.D. (1967). Autoradiographic plaques for the detection of antibody formation to soluble proteins by single cells. Science 156, 964-966.

60. Pryjma, J., Mũnoz, J., Virella, G. \& Fudenberg, H.H. (1980). Evaluation of $\operatorname{IgM}, \operatorname{IgG}, \operatorname{IgA}, \operatorname{IgD}$, and $\operatorname{IgE}$ secretion by human peripheral blood lymphocytes in cultures stimulated with pokeweed mitogen and Staphylococcus aureus Cowan I. Cellular Immunology 50, 115-124.

61. Ramm, L.E., Whitlow, M.B. \& Mayer, M.M. (1984). Complement lysis of nucleated cells: Effect of temperature and puromycin on the number of channels required for cytolysis. Molecular Immunology 21, 1015-1021. 
62. Rector, E.S., Carter, B.G., Kelly, K.A., Lang, G.M. \& Sehon, A.H. (1979). The enumeration of rat IgE-secreting cells using a reverse hemolytic plaque assay. European Journal of Immunology 9, 471-476.

63. Rector, E.S., Lang, G.M., Carter, B.G., Kelly, K.A., Bundesen, P.G., Bottcher, I. \& Sehon, A.H. (1980). The enumeration of mouse IgEsecreting cells using plaque-forming cell assays. European Journal of Immunology 10, 944-949.

64. Reiss, E., Mertens, E. \& Ehrich, W.E. (1950). Agglutination of bacteria by lymphoid cells in vitro. Proceedings of the Society for Experimental Biology and Medicine 74, 732-735.

65. Rotman, B \& Papermaster, B.W. (1966). Membrane properties of living mammalian cells as studied by enzymatic hydrolysis of fluorogenic esters. Proceedings of the National Academy of Sciences of the United States of America 55, 134-141.

66. Sedgwick, J.D. \& Holt, P.G. (1983). A solid-phase immunoenzymatic technique for the enumeration of specific antibody-secreting cells. Journal of Immunological Methods 57, 301-309.

67. Shulman, M., Wilde, C.D. \& Köhler, G. (1978). A better cell line for making hybridomas secreting specific antibodies. Nature 276, 269-270.

68. Šterzl, J. \& Řiha, I. (1965). A localized hemolysis in gel method for the detection of cells producing $7 \mathrm{~S}$ antibody. Nature 208, 858-859.

69. Taylor, G.M. \& Bennett, J. (1973). A modified plaque test for the detection of cells forming antibody to alloantigens. Journal of Immunological Methods 2, 213-219.

70. Terasaki, P.I. \& McClelland, J.D. (1964). Microdroplet assay of human serum cytotoxins. Nature 204, 998-1000

71. Wangel, A.G., Poikonen, H.K. \& Eskola, J (1984). A comparison of three reverse hemolytic plaque assays. Immunobiology 166, 403-409.

72. Weiner, M.S., Bianco, C. \& Nussenzweig, V. (1983). Enhanced binding of neuraminidase-treated sheep erythrocytes to human $T$ lymphocytes. Blood 42, 939-946. 
